\title{
Relation between Energy production and Water in Spain. A particular case for Waste Water Treatment Plants in Granada.
}

Karapet Grigoryan

December 2020

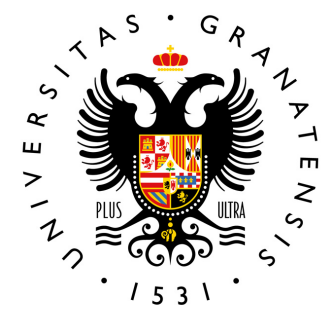

\section{UNIVERSIDAD DE GRANADA}

Supervisors: Fernando Alguacil Duarte \& Francisco González Gómez

Abstract

In recent years the relationship between the energy produced and the amount of fresh water needed in the process is attracting increasing attention. In this work we have carried out a systematic study of that relationship using the Water Footprint (WF) approach. We have compared the contribution of each energy source, distinguishing between renewable and non-renewable, in the production of electricity in Spain during the last three decades, to later relate each energy source to its corresponding consumptive Water Footprint. For comparative purposes, we have also extended our analysis to other European countries and to the region of Andalusia. We also performed a study over a sample of six different-type Waste Water Treatment Plants (WWTP) in the province of Granada to estimate the Used Fresh Water (UFW) along the full chain of treating water in the plants.

Keywords - Water Footprint, WF, Water-energy nexus, Used Fresh Water, UFW, Waste Water Treatment Plats, WWTP 


\section{Resumen}

En los últimos años la relación entre energía producida y cantidad de agua dulce necesaria en el proceso está atrayendo cada vez más interés. En este trabajo hemos llevado a cabo un estudio sistemático de esa relación utilizando el método de la Huella Hídrica (WF). Hemos comparado la contribución de cada fuente de energía, distinguiendo entre renovables y no renovables, en la producción de electricidad en España durante las tres últimas décadas, para luego relacionar cada fuente de energía con su correspondiente Huella Hídrica consumida. Con fines comparativos, también hemos extendido nuestro análisis a otros países europeos y a la región de Andalucía. También hemos realizado un estudio sobre una muestra de seis Estaciones Depuradoras de Aguas Residuales (WWTP), de diferentes tipos, en la provincia de Granada con el objetivo de estimar el Agua Dulce Usada (UFW) a lo largo de toda la cadena de tratamiento del agua en dichas plantas.

Keywords - Huella Hídrica, WF, Nexo agua-energía, Agua Dulce Usada, UFW, Estación Depuradora de Aguas Residuales, WWTP 


\section{Contents}

1 Introduction 4

2 Methodology $\quad 7$

2.1 Water Footprint of electricity for different energy technologies and sources $\quad 7$

3 The Water Footprint in Spain and Europe $\quad 8$

3.1 Water Footprint per energy source in Spain . . . . . . . . . . . . . . 8

3.1.1 Water Footprint of Non-Renewable Energy Sources . . . . . . . . . . 9

3.1.2 Water Footprint of Renewable Energy Sources . . . . . . . . . . . 11

3.2 Water Footprint per energy sources of some European countries . . . . . 13

3.2.1 Nuclear free . . . . . . . . . . . . . . . . . . . . . . . . . . 14

3.2.2 Nuclear dominant . . . . . . . . . . . . . . . 17

4 Water Footprint and Electricity production in the region of Andalusia 20

5 Water Footprint of the energy system in WWTP in the province of Granada 23

5.1 WWTP available data in Granada . . . . . . . . . . . . . . . . . 23

5.2 Typology and energy requirements of the WWTP in the province of Granada 24

5.3 Water Footprint and Used Fresh Water of WWTP in the province of Granada 27

6 Summary and conclusions 31

$\begin{array}{ll}\text { References } & 32\end{array}$

$\begin{array}{ll}\text { A Appendix } & 35\end{array}$

$\begin{array}{lll}\text { B Appendix } & 41\end{array}$ 


\section{Introduction}

Water is life, sustaining ecosystems and regulating our climate, but it is a limited resource. Of all the fresh water on Earth, only $1 \%$ is accessible for direct human use. It is therefore essential that all countries know the value of one of their most precious and scarce resources.

By the global warming warnings, it is very well known that the scarcity of water is elevating day by day. The availability of sufficient quality fresh water is an important issue on present policy agenda in European Union (EU) and in the world. In the year 2000, the EU introduced the Water Framework Directive (WFD), Directive 2000/60/EC [1], representing the most important and comprehensive part of EU legislation ever approved in water policy. In Spain the WFD was immediately carried out through Law 62/2003, of December 30 [2]. The WFD significantly increased the control of the water quality and water discharges to the water basins and rivers, elevating the areas declared sensitive due to the risk of eutrophication and the direct discharges of waste water. As a consequence, for example, the already installed Waste Water Treatment Plants (WWTP) elevated drastically their requirement in water discharge quality.

According to the hispagua article [3], around 500 WWTP were installed in the early 1990s, of which only $40 \%$ met the ecological requirements. Following the implementation of the WFD the number of WWTP increased considerably and now around 2533 are installed throughout Spain, according to the database of the National Water Quality Plan (NWQP) [4]. The availability of water of sufficient quality is an important issue. Understanding the relationship between the water needed for energy production and the energy needed for water supply is therefore essential to understand the balance of water used throughout the water treatment chain. The modernisation and installations of the new WWTP have led Spain to increase the associated energy expenditure. Energy and water are very much interlinked, so that achieving their supply for all countries requires a nexus approach. In 2012, the International Energy Agency (IEA) recognised the importance of the relationship between water and energy. In its annual report of the World Energy Outlook, IEA projects a rise of $85 \%$ in water use for energy production over the next twenty years, related to the expected shift towards more water-intensive power generation and the expanding use of biofuels.

From the point of view of energy production, water is essential. It is used, for example, in extraction, processing and transportation of fuels, to grow biomass for biofuel, also when coal is mined, water is needed for coal washing (coal preparation), dust suppression and machine cooling. At the same time, water can be produced from the mines, which is often polluted and needs to be treated before discharge or recycling. For oil, when the pressure in an oil reserve decreases, water can be injected into the wells to drive the oil out. For uranium, consumption of water is needed, when the uranium ore is mined and converted to uranium fluoride, but it occurs most significantly in the process of enrichment of uranium. In addition, water is also used to produce energy in Thermal and Nuclear power plants (TPP/NPP) and Combined Heat and Power plants (CHP). 
The fastest growing form of energy is electricity production. Figure 1 shows the increase in electricity production (in units of GWh) in Spain from 1990-2018. It distinguishes between non-renewable (TPP/NPP/CHP) and renewable sources, hydro-power (hydroelectricity), solar energy (captured through either concentrated solar power (CSP) or photo-voltaic (PV systems), wind energy (wind electricity) and burning biomass (bioelectricity).

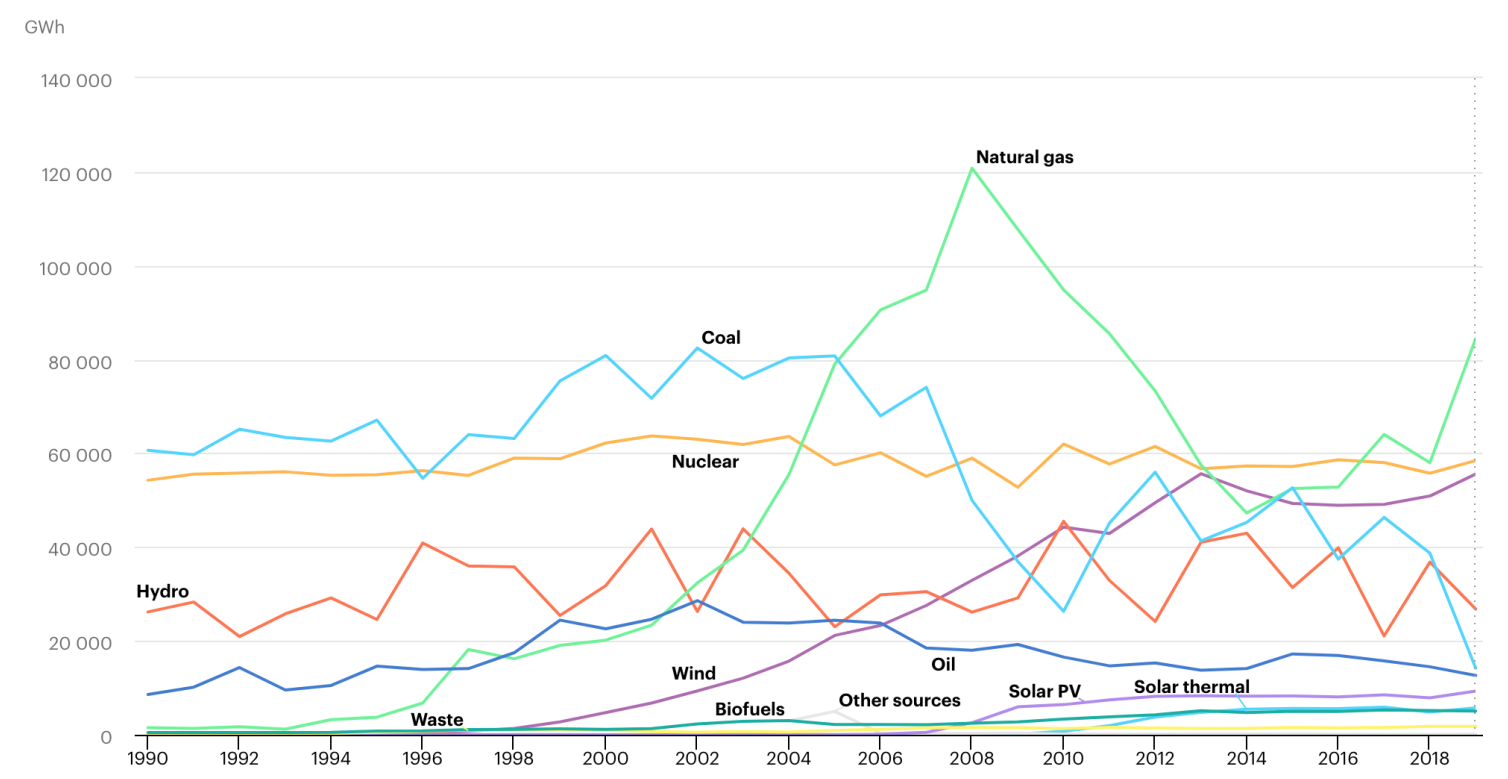

Figure 1: Increase in electricity production in Spain from 1990-2018, provided by the International Energy Agency (IEA) [5].

The consume of electricity is everywhere, including Waste Water Treatment Plants. Actually, the WWTP present quite high total electricity demand. In United States it has been estimated that roughly $4 \%$ of the electricity demand is employed for potabilization and distribution of water as well as collection and treatment of wastewater. In Spain, some studies demonstrate that domestic and industrial water cycles account for $2-3 \%$ of total electric energy consumption, and considering water management and agricultural demand, could reach $4-5 \%$. The 2533 WWTP currently running in Spain generate a flow of $3375 \mathrm{hm}^{3}$ of treated wastewater per year. In the case of Andalucia region, according to National Plan for Water Quality database, around 545 WWTP are registered, which generate $520.07 \mathrm{hm}^{3} /$ year of recovered water.

The main purpose of my Master Thesis Work is to investigate the interlink between the electricity production and the used freshwater in the process. We will put a particular interest in the case of Waste Water Treatment Plants of different types, with our casestudy in the province of Granada. In this last case, we want to answer the question: How much fresh water do we use to treat the water? To develop our studies we have applied a method called "Water Footprint" (WF) [6], which represents a crucial part of our study. 
In 2002 the Water Footprint concept was introduced by professor Arjen Hoekstra, in order to have a consumption-based indicator of water use, that could provide useful information in addition to the traditional production-sector-based indicators of water use. The WF approach considers the place where water is consumed, the type of water used and when it is used. In fact, WF measurements can be computed for given areas, regions or even for nations. In addition, it introduces the concept of blue, green and gray water footprint: i) the concept of blue WF measures the consumptive use of surface and groundwater, water from lakes, reservoirs and river basins, ii) the concept of green WF is the amount of water from precipitation that is stored in the root zone of the soil and evaporated, transpired or incorporated by plants, iii) the concept of grey WF, used as an indicator of water pollution, represents the volume of freshwater that is required to assimilate the load of pollutants based on natural background concentrations and existing ambient water quality standards.

Continuing with the objective of understanding and optimizing the use of water, and taking into account that water treatment facilities represent about the $4 \%$ of the total energy demand in a country like Spain, it will be also important and necessary to understand what the net water balance is in the entire water treatment chain. For this purpose, in addition to tracking the WF, which will tell us the volume of water consumed for energy production, we will also need to know the amount of energy used to treat a certain volume of water. To connect these two quantities, in this work we have introduced the new term "Used Fresh Water" (UFW), expressed in units of volume per volume (e.g. $\mathrm{m}^{3} / \mathrm{m}^{3}$ ). It is defined as the relationship between the amount of fresh water used in the energy production phase (i.e. WF), and the total energy consumed per volume of water treated in a WWTP. All this is especially relevant in countries like Spain where there are regions, such as Andalusia, that are becoming increasingly dry and water is becoming a very precious asset.

Work plan. This Master Thesis is organised as follows:

- We start in Section 2 with a brief introduction about the methodology to estimate the Water Footprint in the electricity production for different energy sources.

- In Section 3.1 we describe the main energy sources in Spain and calculate the WF associated to each of them. For completeness, and by way of comparison, we continue in Section 3.2 describing briefly the "energy source - WF" relationship for different EU countries with very different sources of energy contributing to their electricity production.

- We continue in Section 4 studying the particular case of the region of Andalusia.

- And finally, in Section 5 we focuss in the Waste Water Treatment Plants in the province of Granada, to study the balance between "used fresh water versus treated water" in these systems. 


\section{Methodology}

\subsection{Water Footprint of electricity for different energy technologies and sources}

The water footprint of electricity, named by WF, and expressed in units of $\mathrm{m}^{3} / \mathrm{TJ}$, refers to the volume of water consumed at different stages of the energy production process. The absence of data for water pollution (from mining and chemical loads from the power plants) prevented us to include the grey WF component in our study, limiting us to the use of only the blue and green components, thus underestimating the total WF of electricity obtained in this work.

Water Footprint studies typically distinguish between three main stages of electricity production: fuel supply, construction and operation. The first stage is only relevant for electricity production based on coal, oil, natural gas, uranium and biodiesel. In the other cases under study (hydro, solar and wind), this is negligible or nonexistent. Therefore, in the last cases we only consider the remaining two production stages (i.e. construction and operation). The European Commission's science and knowledge service has conducted the most geographically detailed consumptive WF assessment for the EU to date, based on the newest spatial databases of energy sources [7]. For the work presented in this document, we have used the values of the Water Footprint, per energy source and stage, predicted in [7], and summarized in Table 1.

\begin{tabular}{|c|c|c|c|}
\hline Energy source & $\begin{array}{c}\text { Fuel supply } \\
{\left[\mathrm{m}^{3} / \mathrm{TJ}\right]}\end{array}$ & $\begin{array}{c}\text { Construction } \\
{\left[\mathrm{m}^{3} / \mathrm{TJ}\right]}\end{array}$ & $\begin{array}{c}\text { Operation } \\
{\left[\mathrm{m}^{3} / \mathrm{TJ}\right]}\end{array}$ \\
\hline Coal & 134 & 1 & 437 \\
\hline Oil & 73 & 1 & 175 \\
\hline Natural Gas & 5 & 1 & 130 \\
\hline Nuclear & 60 & 0.3 & 567 \\
\hline Hydropower & 0 & 1 & 9113 \\
\hline Wind & 0 & 1 & 0.2 \\
\hline Solar & 0 & 90 & 27 \\
\hline Biodiesel & 3279 & 1 & 0 \\
\hline Biodiesel & 134345 & 1 & 0 \\
\hline
\end{tabular}

Table 1: Average blue and green Water Footprint related to energy production in EU taken from [7]. Note that for the case of biodiesel the operation contribution to the WF is below the percent level (zero in our calculations) in comparison with the fuel supply phase [8].

Based on the procedures described in [6] and [9], the total WF of electricity, $\mathrm{WF}_{\text {total }}$, is calculated by

$$
W F_{\text {total }}=\left(W F_{f}+W F_{c}+W F_{o}\right) \times E
$$

where $\mathrm{WF}_{f}$ is the average water footprint of the fuel supply per unit of electricity, $\mathrm{WF}_{c}$ is the average water footprint associated with the construction phase of the power plant expressed in units of electricity produced for the entire duration of the plant, and $\mathrm{WF}_{o}$ is the average water footprint in the operational phase per unit of electricity produced by fuel or renewable energy source (Table 1). E represents the annual production of electricity from fuel and renewable energy sources. 


\section{The Water Footprint in Spain and Europe}

\subsection{Water Footprint per energy source in Spain}

Following the methodology explained in section 2.1 we have performed a systematic study of the Water Footprint in Spain for the time period 1990 - 2018. Table 2 shows the different values of E in TJ, per year and energy source, used in this work. We obtained this data from a database provided by the EU Open Data Portal [10]. Regarding coal and biodiesel data, the database distinguish between contributions from brown and hard coal, and from biogas and solid biofuel. In our study (numbers in Table 2) we have added together both contributions in each case.

\begin{tabular}{|c|c|c|c|c|c|c|c|c|}
\hline Year & $\begin{array}{c}\text { Coal } \\
{[\mathrm{TJ}]}\end{array}$ & $\begin{array}{l}\text { Oil } \\
{[\mathrm{TJ}]}\end{array}$ & $\begin{array}{l}\text { Natural } \\
\text { Gas [TJ] }\end{array}$ & $\begin{array}{c}\text { Nuclear } \\
\text { [TJ }\end{array}$ & $\begin{array}{c}\text { Hydro } \\
{[\mathrm{TJ}]}\end{array}$ & $\begin{array}{c}\text { Wind } \\
{[\mathrm{TJ}]}\end{array}$ & $\begin{array}{c}\text { Solar } \\
{[\mathrm{TJ}]}\end{array}$ & $\begin{array}{c}\text { Biodiese } \\
{[\mathrm{TJ}]}\end{array}$ \\
\hline 1990 & 214113.6 & 30974.4 & 5432.4 & 195364.8 & 94248 & 36 & 36 & 1944 \\
\hline 1991 & 211640.4 & 36561.6 & 4899.6 & 200080.8 & 101844 & 72 & 36 & 1944 \\
\hline 1992 & 231199.2 & 51584.4 & 6159.6 & 200815.2 & 75348 & 360 & 36 & 2052 \\
\hline 1993 & 224701.2 & 34358.4 & 4305.6 & 201600 & 92808 & 432 & 36 & 2088 \\
\hline 1994 & 221626.8 & 37832.4 & 11624.4 & 199126.8 & 105048 & 648 & 72 & 2304 \\
\hline 1995 & 238896 & 52642.8 & 14400 & 199638 & 88452 & 972 & 72 & 3636 \\
\hline 1996 & 194198.4 & 50400 & 24361.2 & 201600 & 147132 & 1296 & 72 & 3924 \\
\hline 1997 & 225615.6 & 50770.8 & 65426.4 & 199072.8 & 129600 & 2664 & 72 & 5256 \\
\hline 1998 & 220644 & 62996.4 & 58363.2 & 212374.8 & 128916 & 4860 & 72 & 5508 \\
\hline 1999 & 265006.8 & 88002 & 68608.8 & 211867.2 & 91584 & 9864 & 108 & 5832 \\
\hline 2000 & 284731.2 & 81280.8 & 72640.8 & 223941.6 & 114516 & 17028 & 36 & 5400 \\
\hline 2001 & 252961.2 & 88675.2 & 84088.8 & 229348.8 & 157896 & 24336 & 72 & 5868 \\
\hline 2002 & 292240.8 & 102934.8 & 116589.6 & 226857.6 & 94572 & 33624 & 72 & 9288 \\
\hline 2003 & 269002.8 & 86407.2 & 141724.8 & 222750 & 158040 & 43488 & 72 & 11484 \\
\hline 2004 & 284792.4 & 85820.4 & 198000 & 228981.6 & 123984 & 56520 & 72 & 11952 \\
\hline 2005 & 284594.4 & 86400 & 284439.6 & 207140.4 & 82872 & 76248 & 180 & 9540 \\
\hline 2006 & 240249.6 & 85784.4 & 327600 & 216453.6 & 107388 & 83880 & 432 & 9972 \\
\hline 2007 & 262054.8 & 66628.8 & 341276.4 & 198370.8 & 109872 & 99252 & 1872 & 10440 \\
\hline 2008 & 175366.8 & 64807.2 & 434872.8 & 212302.8 & 94104 & 118620 & 9288 & 11700 \\
\hline 2009 & 129265.2 & 69271.2 & 387885.6 & 189939.6 & 104976 & 137232 & 21816 & 12564 \\
\hline 2010 & 91195.2 & 59623.2 & 341463.6 & 223200 & 163836 & 159372 & 25884 & 14472 \\
\hline 2011 & 158331.6 & 52891.2 & 307828.8 & 207784.8 & 118476 & 154512 & 33840 & 16596 \\
\hline 2012 & 198259.2 & 55155.6 & 263908.8 & 219600 & 86976 & 178092 & 43092 & 17928 \\
\hline 2013 & 143798.4 & 49546.8 & 207129.6 & 204213.6 & 147780 & 200340 & 47160 & 20880 \\
\hline 2014 & 157690.8 & 50835.6 & 170182.8 & 206298 & 154692 & 187236 & 49212 & 19512 \\
\hline 2015 & 184924.8 & 62067.6 & 188992.8 & 205905.6 & 112932 & 177588 & 49896 & 20736 \\
\hline 2016 & 131169.6 & 60915.6 & 190800 & 211078.8 & 143532 & 176076 & 49104 & 20484 \\
\hline 2017 & 162446.4 & 56757.6 & 230533.2 & 208940.4 & 75852 & 176868 & 51840 & 21888 \\
\hline 2018 & 134416.8 & 52192.8 & 208814.4 & 200757.6 & 132480 & 183240 & 45864 & 21240 \\
\hline
\end{tabular}

Table 2: Annual amount of produced electricity in Spain, by energy source in TJ, taken form [10]. 
In this study we have differentiated between:

- Non-Renewable energy sources: coal, oil, natural gas and nuclear.

- Renewable energy sources: hydropower, wind, solar and biodiesel.

\subsubsection{Water Footprint of Non-Renewable Energy Sources}

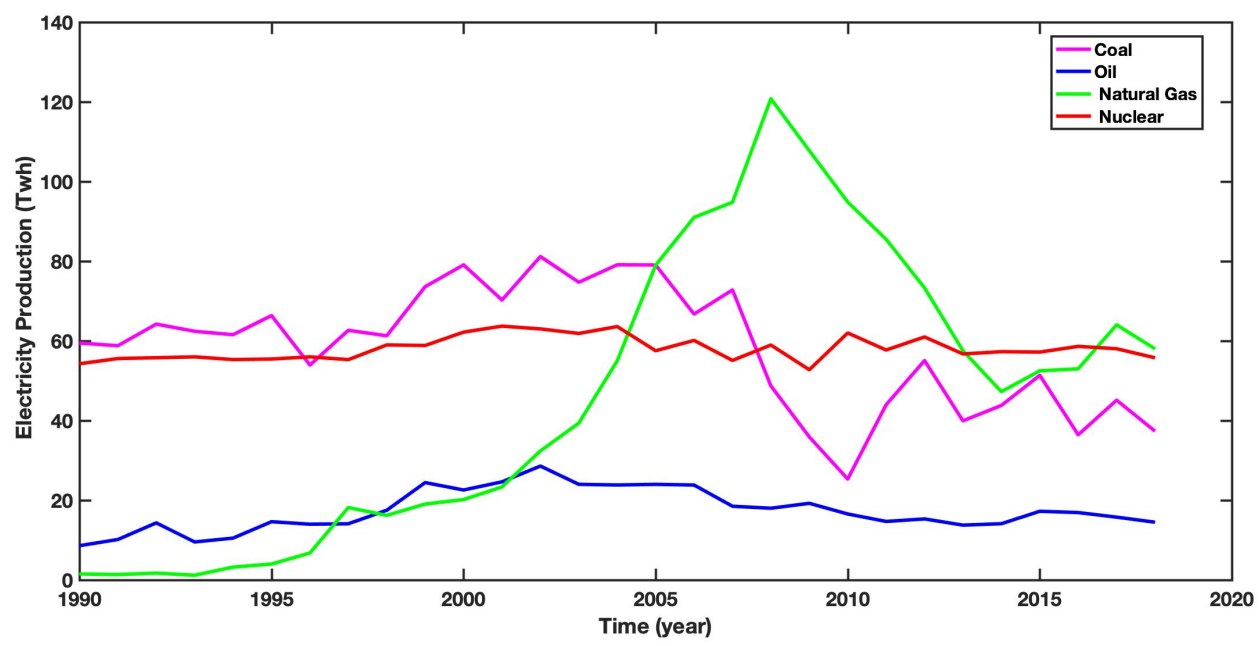

Figure 2: Electricity production of non renewable energy sources in Spain from 19902018.

Figure 2 shows the electricity production (in Twh) for non-renewable energy sources in Spain for the time period of 1990 - 2018. From the figure, several features are easily observed. Nuclear and oil based electricity production remain almost constant in all the time period under study. On the contrary, for the case of coal and natural gas a dramatic change in trend is observed, with its inflection point in around the year 2005. Before that year, coal represents the maximum energy source in the electricity production, but after that year it suffers a dramatic drop (larger than a 50\%) that lasts several years. On the contrary, the gas natural experiments the opposite behaviour, raising from the minimum weight in the electricity production, to represent the maximum contribution from 2005 (a big drop is observed also from 2009, but still being among the main contributions of its group). This anticorrelated trend between coal and natural gas can be understood by multiple reasons. One of them is the Spanish (and world) economical crisis suffered during that period and the fact that about $90 \%$ of the coal used in Spain is imported from other countries. Indeed, according to [11], in 2017, when Spain was more economically recovered, the trend in the coal importation increased by $28.5 \%$ in comparison with previous years. 


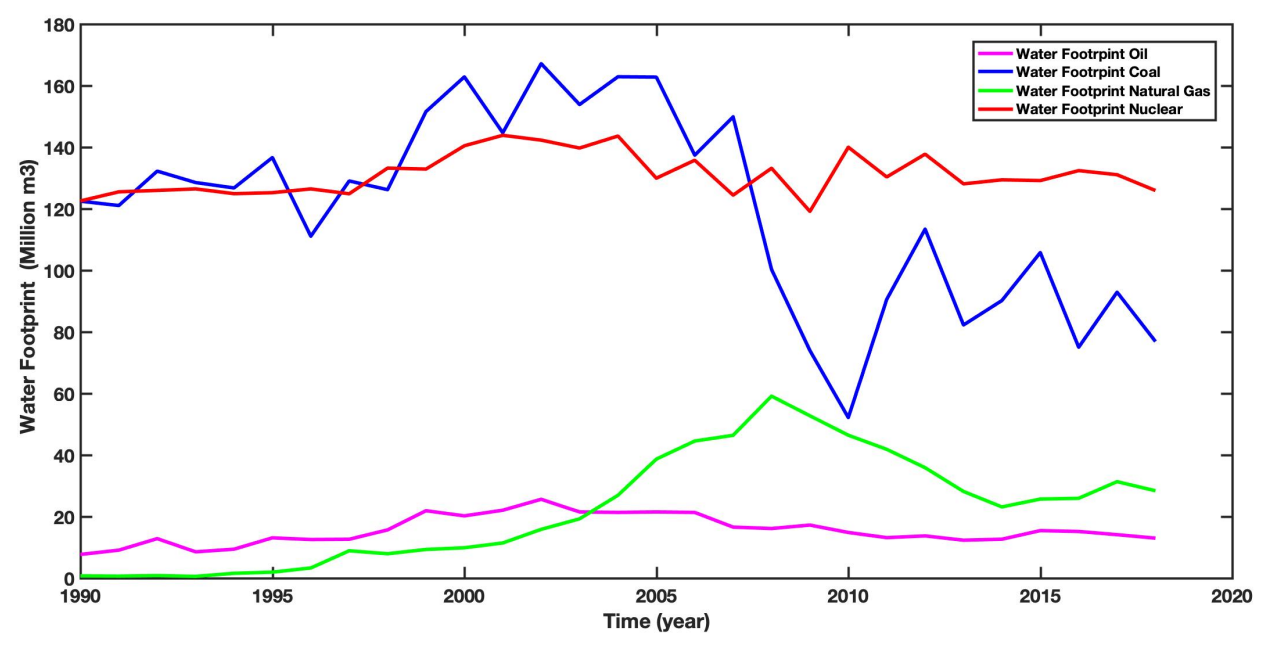

Figure 3: Estimated Water Footprint per non-renewable energy sources in Spain for the time period 1990 - 2018. Calculations have been made using MatLab package [12], shown in Appendix A.

Another and very important reason for that decrease was the reduction of the greenhouse gas (GHG) emissions, for environmental purposes. Carbon dioxide $\left(\mathrm{CO}_{2}\right)$ makes up the vast majority of greenhouse gas emissions from the energy sector, but smaller amounts of methane $\left(\mathrm{CH}_{4}\right)$ and nitrous oxide $\left(\mathrm{N}_{2} \mathrm{O}\right)$ are also emitted. These gases are released during the combustion of fossil fuels, such as coal, oil, and natural gas, on the phases of the production of electricity, but in very different amounts. For example, based on [13], the GHG emission from coal, has an average value of $0.3295 \mathrm{~kg} \mathrm{CO}_{2} / \mathrm{kWh}$, which is a factor $\times 2$ larger than the contribution from natural gas, with a value of $0.182 \mathrm{~kg}$ $\mathrm{CO}_{2} / \mathrm{kWh}$. Following both i) the United Nations Framework Convention on Climate Change and its Kyoto Protocol, and later ii) the European Union legislation, Spain was forced to reduce its GHG emissions. In particular, for the period from 2008 to 2012, the first commitment period of the Kyoto Protocol, Spain had to limit the increase in its GHG up to $15 \%$ of the level of emissions in the reference years (1990-1995). Furthermore, from the period 2013 - 2020 during the European Energy and Climate Change Package, Spain and all EU member countries adopted the policy of the reduction of their GHG emission up to $20 \%$. All this translated in favouring energy sources like natural gas with a small contribution to the GHG emissions in comparison with other preferred sources before, like coal (as seen in Figure 2).

Figure 3 shows the total WF (in million $\mathrm{m}^{3}$ ) for the electricity production and energy sources showed in figure 2. As WF and E presents a linear dependency (see Equation 2.1), the trends in time described before (for E) are the same for the WF. But the important thing now are also the absolute values of the different components. The WF coming from nuclear and coal sources represent about a factor $\times 5$ larger than for the case of oil and natural gas. The case of natural gas is particularly relevant, in the sense that, while being nowadays the main (or among them) electricity producer in Spain (since 2005) its WF remains significantly small in comparison with its closer competitors. This last makes gas natural the better non-renewable energy source in Spain in the balance electricity WF generated. 


\subsubsection{Water Footprint of Renewable Energy Sources}

Spain has a lot of potential to grow its electricity production through renewable energy sources, which in the other hand will include the benefit of reducing the emission of GHG. And in fact, in the last two decades renewable energy in Spain has become the fastest growing form of electricity production. Figure 4 shows the electricity production (in Twh) for renewable energy sources in Spain for the time period of 1990 - 2018. As we can observe, the electricity production through renewable energy sources has increased, in opposition to the case of non-renewable sources (with the exception of natural gas) described in the previous section. This increase is particularly obvious for the case of wind production, becoming even larger than the contribution from hydro power plants (the dominant source from previous years). Nowadays, Spain is the leader in wind power generation being the country that has installed the most onshore capacity in the EU by 2019 [14] (15\% of the total in Europe). In that year, wind power contributed $20.8 \%$ of the electricity consumed (in 2018 it was 19\%), avoiding both $28 \mathrm{Mton}^{\mathrm{CO}_{2}}$ and imported 10.7 Mtoe (Mega tonne of oil equivalent) of fossil fuels.

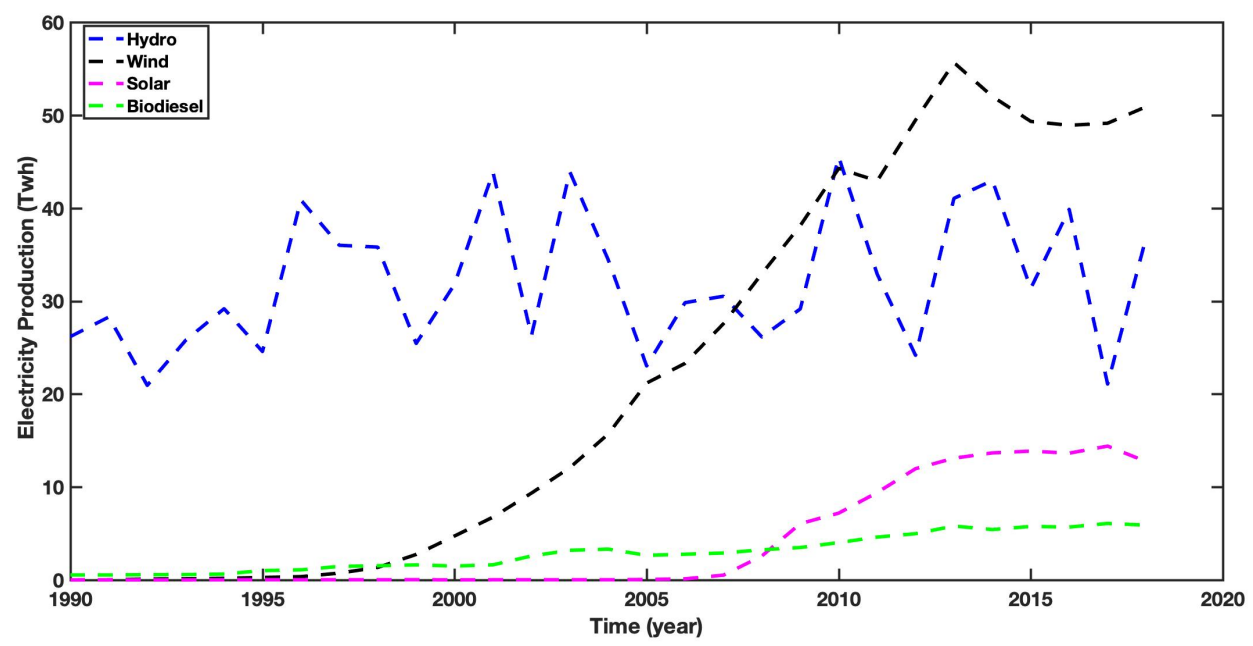

Figure 4: Electricity production by renewable energy sources in Spain from 1990-2018.

Since 2009, wind has been the technology that has contributed most to total renewable energy generation, as can be seen in Figure 4. This is due mainly to the fact that installed wind power capacity has grown year on year and because of its regularity in terms of annual generation. In fact, unlike hydro, whose dependence on meteorological conditions is extremely high, wind energy production is much more constant throughout the year, although it too has a certain degree of dependence on meteorological conditions.

Hydro together with wind are the leaders of the electricity production of renewable energy source. Meanwhile their WF are significantly different as shown in Figure 5. This is due to their extremely different, more than 4-orders of magnitude, WF during their operation phases (Table 1). For example, in 2010 the produced electricity by hydro and wind powers were very similar, $45.51 \mathrm{Twh}$ and $44.27 \mathrm{Twh}$, while their WF values were 1493 million $\mathrm{m}^{3}$ and 0.1912 million $\mathrm{m}^{3}$ respectively ( $\times 7800$ different). And if we take into account all the time period under study, the average WF from wind and hydro are 0.0953 million $\mathrm{m}^{3}$ and 1049.6 million $\mathrm{m}^{3}$ respectively. 


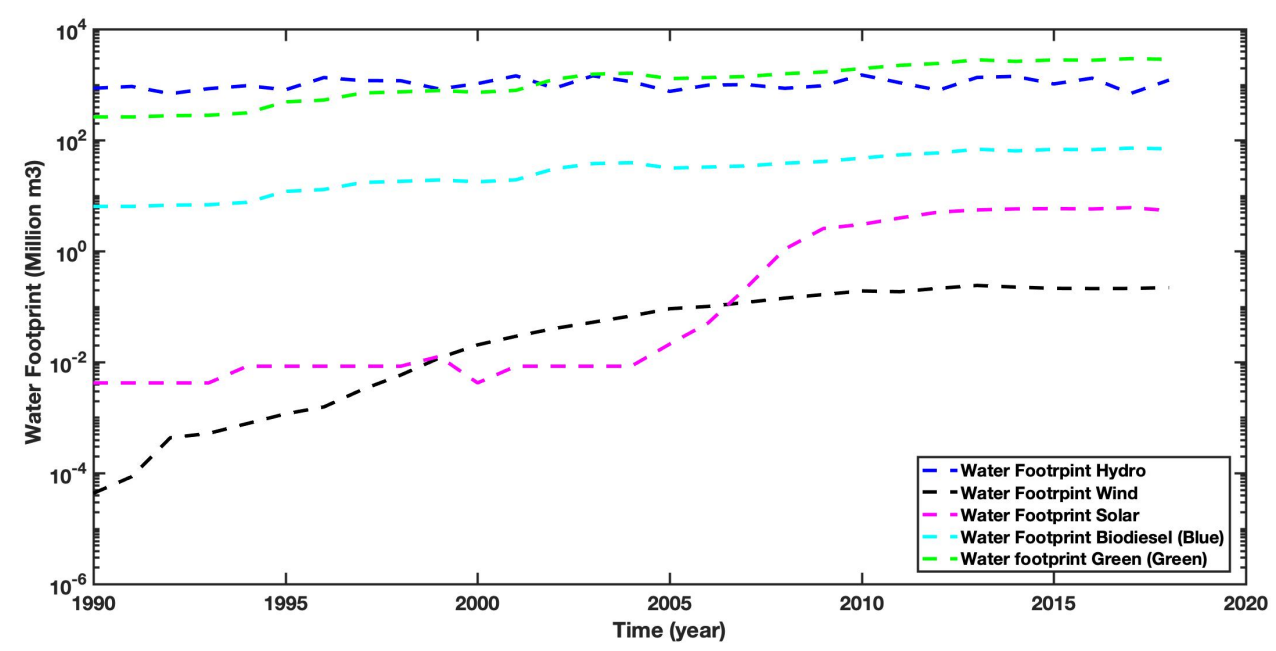

Figure 5: Calculated Water Footprint per renewable energy sources in Spain from 19902018.Note the y-axis logarithmic scale. Calculations have been made using MatLab package [12], shown in Appendix A.

The use of solar energy for electricity production has also grown in the last years, but it is still quite far from hydro and wind production. From the point of view of WF, solar energy source is also not competitive with wind. From Figures 4 and 5, we see how for an energy production about $\times 4$ smaller, the solar WF is more than one order of magnitude larger that the wind one.

The most extreme case in the E - WF balance is for the biodiesel energy source. In Figure 4 we see how electricity production by biodiesel presents a systematic increase with time. However, of all the renewable energy sources under study, it is the one that contributes least to electricity production in Spain. On the other hand, biodiesel presents the largest, by far, green and blue WF component (Table 1) from the production phase, due to irrigation, agricultural production and evapotranspiration. Its green component of WF is larger than the blue by about a factor $\times 41$. According to reference [15], WF of biodiesel can be in the range of $\times 70-400$ larger than the other primary energy carriers (excluding hydro), what is in agreement with our results showed in Figure 5 (note the log-scale in the y-axis). The product source of biomass and biogass, whose total sum is represented as the biodiesel term in Table 2, can be very diverse. Biomass is a shadow term for all the material flows that derive from the biosphere, such as food and feed crops, energy crops, and organic wastes, such as manure and crop residues. Biogas is a combustible gas that is generated in natural environments or in specific devices, by the biodegradation reactions of organic matter, through the action of microorganisms and other factors, in the anaerobic environment. 
For example, the green and blue WF of biomass produced by maize in Brazil is $39.4 \mathrm{~m}^{3} / \mathrm{GJ}$ (or $663.9 \mathrm{~m}^{3} /$ Tonne), by sugar beet in Netherland is $13.4 \mathrm{~m}^{3} / \mathrm{GJ}$ (or $50.5 \mathrm{~m}^{3}$ / Tonne) and in United States is $23.3 \mathrm{~m}^{3} \mathrm{GJ}$ (or $87.7 \mathrm{~m}^{3} /$ Tonne) [15]. For the case of Bioethanol, the WF produced by maize in Brazil is $110 \mathrm{~m}^{3} / \mathrm{GJ}$ (with $39 \%$ blue WF and $61 \%$ green WF), while the value for sugar beet in United States is $59 \mathrm{~m}^{3} / \mathrm{GJ}$ (with $59 \%$ blue WF and 41\% green WF) [16]. As illustrated with the numbers above, the total green and blue WF based on their primary product to produce biodiesel is very diverse. However, the database used for this work didn't have available that information, distinguishing only between whole blue and green WF contributions (as shown in Table 1).

Regarding Spain, in the last two decades the average WF of biodiesel source is 1454.2 million $\mathrm{m}^{3}$, with more than $97 \%\left(1419.6\right.$ million $\left.\mathrm{m}^{3}\right)$ coming form the green WF component and only about a $3 \%\left(34.6\right.$ million $\left.\mathrm{m}^{3}\right)$ from the blue. In fact, only the green component of biodiesel WF is covering almost $50 \%$ of total WF demand in Spain. As a comparative example of blue and green WF in Spain, the amount of electricity generated from biodiesel integrated in the full time period under study is 85.1 Twh. A comparable amount of energy was generated from hydropower plants only within 2007 and 2013. The WF in both cases were 42173 million $\mathrm{m}^{3}$ (97\% green and $3 \%$ of blue through biobiesel) and 2348 million $\mathrm{m}^{3}$ (blue through hydro) respectively (almost a $\times 17$ factor difference).

Table 3 summarises the fraction of the different energy sources contributing to the electricity production and WF in Spain for the year 2018, which is the closest year to the current date included in our study. From the table one can clearly identify the sources contributing more and less to both E and WF.

\begin{tabular}{|c|c|c|c|c|c|c|c|c|}
\hline $\begin{array}{c}\text { Spain in } \\
2018\end{array}$ & $\begin{array}{c}\text { Coal } \\
{[\%]}\end{array}$ & $\begin{array}{c}\text { Oil } \\
{[\%]}\end{array}$ & $\begin{array}{c}\text { Natural } \\
\text { Gas [\%] }\end{array}$ & $\begin{array}{c}\text { Nuclear } \\
{[\%]}\end{array}$ & $\begin{array}{c}\text { Hydro } \\
{[\%]}\end{array}$ & $\begin{array}{c}\text { Wind } \\
{[\%]}\end{array}$ & $\begin{array}{c}\text { Solar } \\
{[\%]}\end{array}$ & $\begin{array}{c}\text { Biodiesel } \\
{[\%]}\end{array}$ \\
\hline$\langle\mathrm{E}\rangle$ & 13.72 & 5.33 & 21.32 & 20.5 & 13.53 & 18.71 & 4.68 & 2.17 \\
\hline$\langle\mathrm{WF}\rangle$ & 1.75 & 0.29 & 0.64 & 2.87 & 27.56 & 0.005 & 0.12 & 66.73 \\
\hline
\end{tabular}

Table 3: Fraction of the different energy sources contributing to the electricity production and WF in Spain for the year 2018.

\subsection{Water Footprint per energy sources of some European countries}

For completeness, we have include in our study the WF (blue and green) for some European Union (EU) countries in the time period 2008 - 2012. The selection of this particular period is motivated because those years are the only ones when complete and reliable data for the variables used in our work could be found [10]. Among all the EU countries we have selected a sample of six: Italy, Greece, Portugal, Sweden, Poland and France. Our selection has been driven trying to cover very different situations from the point of view of production electricity sources, e.g. from nuclear free to dominant contributions (see Figure 6). 


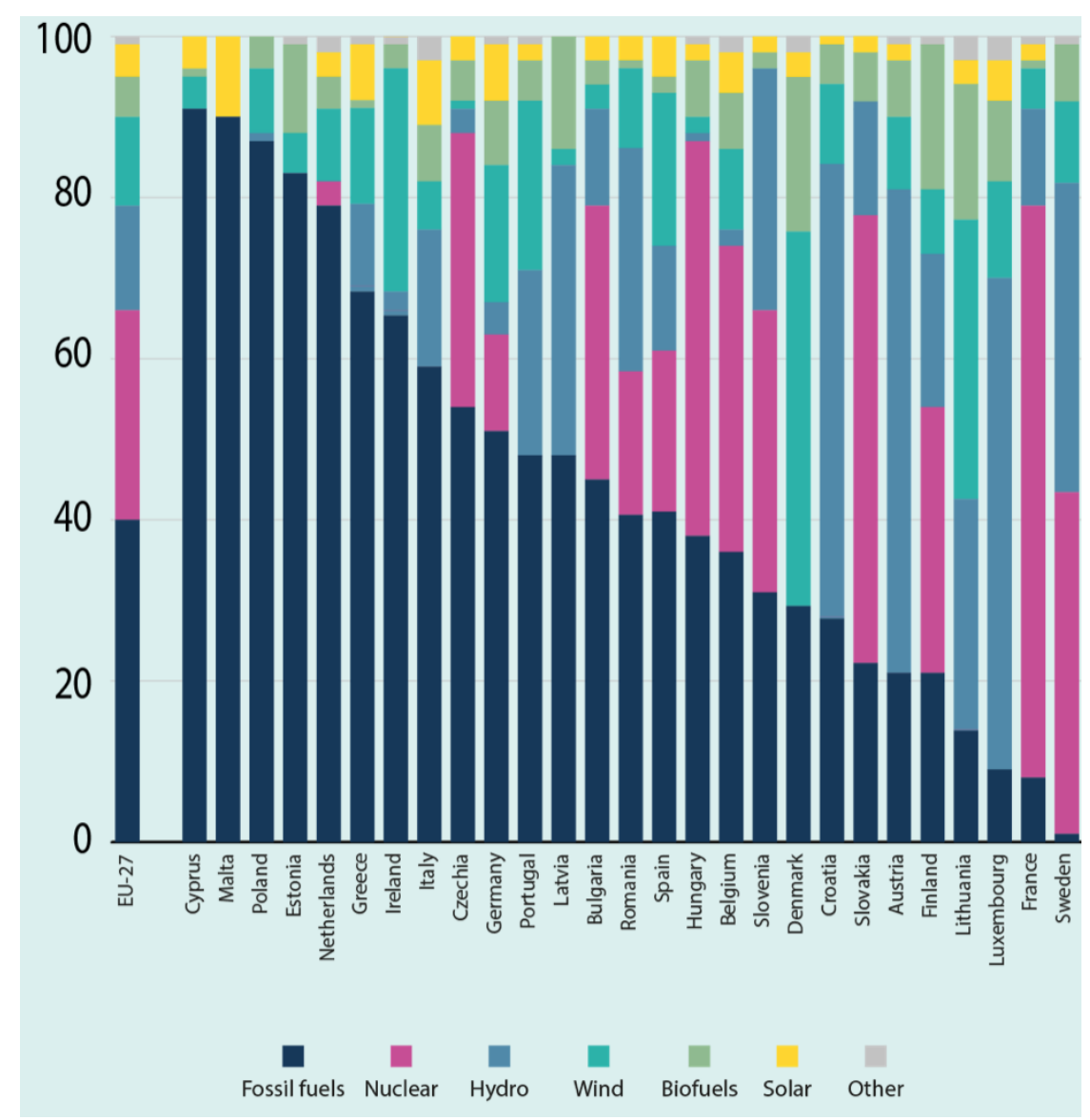

Figure 6: EU electricity production by energy source in 2018, from database eurostat [17].

\subsubsection{Nuclear free}

In Italy, the main electricity productions are through fossil fuel and hydro, representing the $62 \%$ and $17 \%$ respectively, for the time period that we are studying. Biodiesel and wind present very similar and smooth trends in time, while in the case of solar source, it is observed a rise in time of almost 2-orders of magnitude (see Figure 7). If we look to the WF, represented in Figure 8, the situation is very different: for our time period the average produced electricity by fossil fuel is 216.14 Twh with a WF of 83.35 million $\mathrm{m}^{3}$, while the electricity production through hydro is $49.33 \mathrm{Twh}$, with 1061.879 million $\mathrm{m}^{3}$ of WF. But are biodiesel together with hydro the electricity sources representing the dominant contribution to the total WF in Italy.

Figure 7 also shows that in Greece (similarly than in Italy) the dominant electricity production source is the fossil fuel representing a $66 \%$ of total electricity demand. But in this case, renewable energy sources represent the remaining $34 \%$. Among the renewable energy sources, hydro and wind are the leaders in the electricity production, as it was observed in Spain. The biodiesel evolution in time is almost flat, while in the case of solar energy, there is again an increase of more than two orders of magnitude for the period under study. In the context of WFs (Figure 8), the dominant contributions in Greece are hydro (49\%) and biodiesel (28.5\% of the total WF with $27.8 \%$ green and $0.7 \%$ blue), together with fossil fuel (22.4\%). 

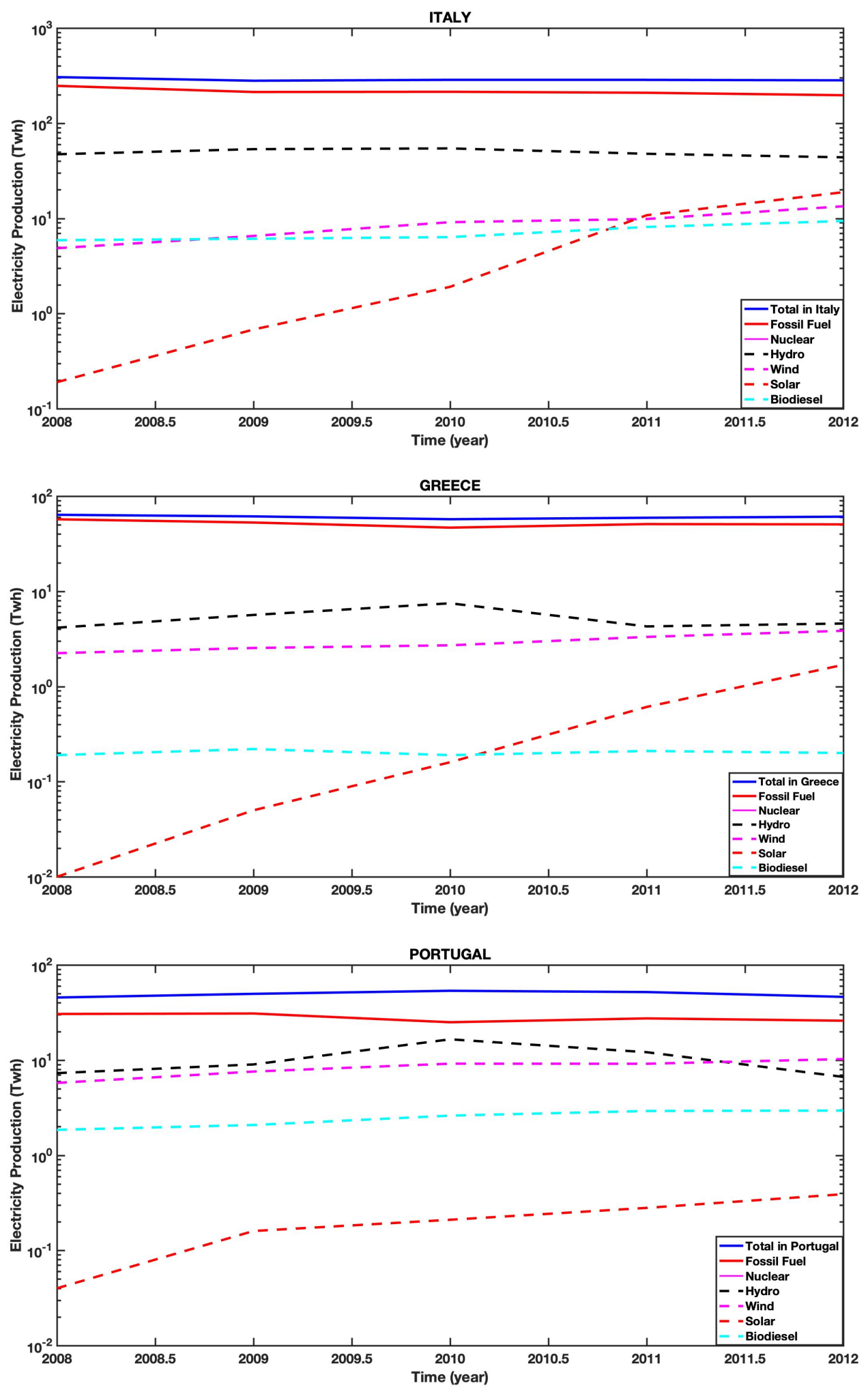

Figure 7: Electricity production per energy source for some EU countries nuclear energy free (note the y-axis logarithmic scale). 

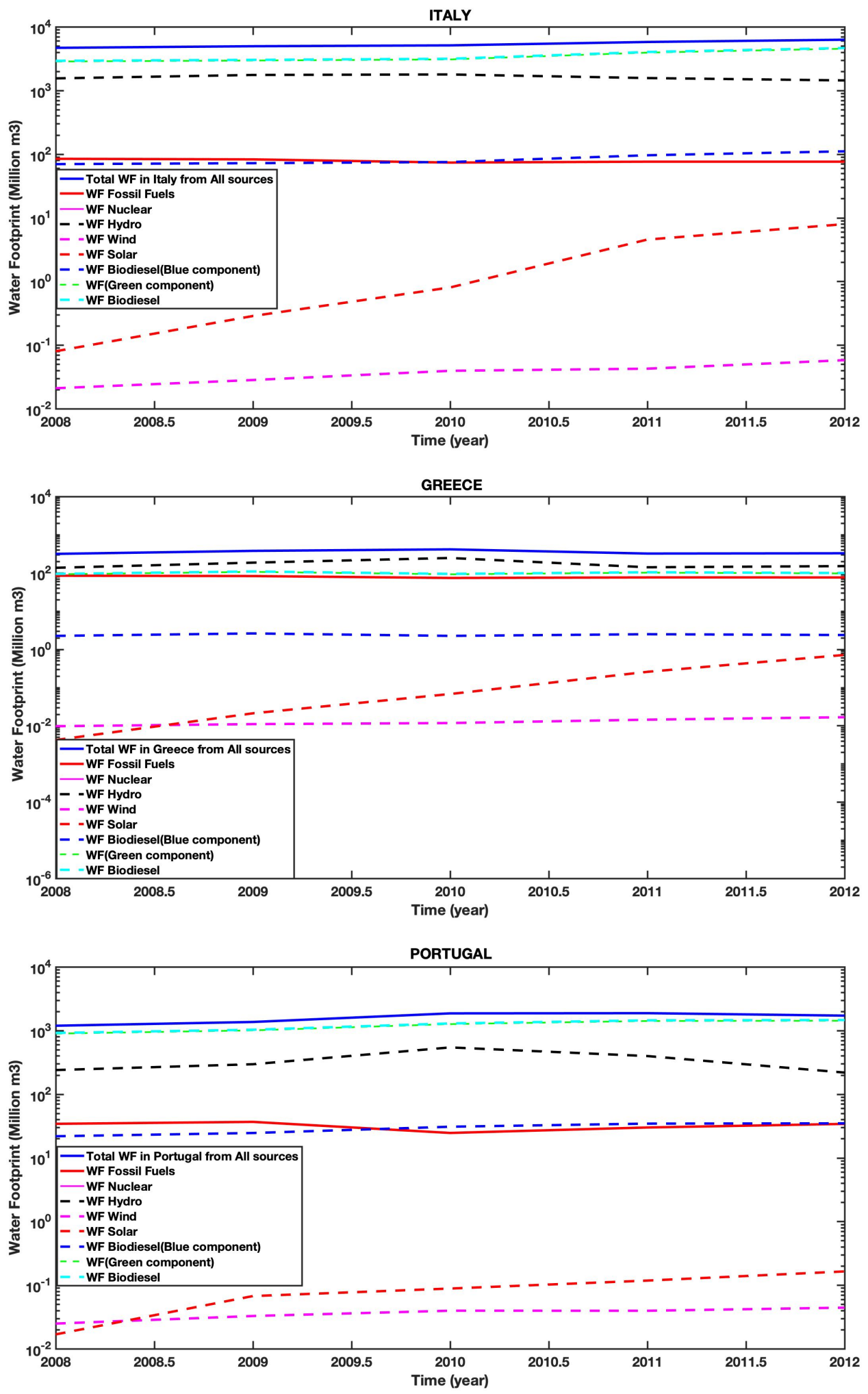

Figure 8: Water Footprint per energy source for some EU countries nuclear energy free (note the y-axis logarithmic scale). 
In Portugal, the electricity production can be divided into fossil fuel and renewable sources each representing a $50 \%$ of the total contribution. Based on Figure 7 , among the renewable energies, hydro and wind are the dominant sources with the second prevailing at the end of the period. As previously, biodiesel shows a stable behaviour in time while the solar contribution increases, but in the case of Portugal at a significantly lower rate than for Italy and Greece. In terms of WF (Figure 8) for the major electricity producers we have $21 \%$ for hydro, $2 \%$ for fossil fuel and $0.002 \%$ for wind. It is important to mention that biodiesel, while being relatively marginal in the whole electricity production in Portugal, it contributes with the $76 \%$ of total WF demand, making it the main WF holder in Portugal.

For the three countries discussed above, the higher consume of blue and green WF is detected for biodiesel and hydro power sources. This places Italy at the forefront of WF consumption among the three.

As happens with Italy, Greece and Portugal, Poland is a nuclear free country. The main electricity producers in Poland, representing almost the $88 \%$ of the total generation, are burning fossil fuels like coal, natural gas and oil. Regarding renewable energy sources, that represent the $12 \%$ of total production, a smooth growing trend can be observed in the time period under study (Figure 9). This growth means a reduction in greenhouse gas emissions, in particular for carbon dioxide $\left(\mathrm{CO}_{2}\right)$, which is one of the main GHG released through the burning of fossil fuel. In recent decades the GHG in Poland has been reduced almost a factor $\times 1.5$, comparing with 1990 [18]. Although the leading electricity production is through fossil fuel, in terms of blue and green WF the situation is significantly different. Coal, which is the main source of fossil fuel for electricity production in Poland, represents $81 \%$ of total electricity demand, but only $8 \%$ of total WF for the 2008-2012 study period. Most of the WF is distributed among fossil fuel, hydropower and primarily biodiesel. Average electricity production using fossil fuel alone is $144.46 \mathrm{Twh}$, representing 286.21 million $\mathrm{m}^{3}$ of WF, which corresponds to only $12.68 \%$ of total WF. The largest contribution to blue and green WF comes from biodiesel, with an average of 3254.14 million $\mathrm{m}^{3}$, while its electricity production corresponds to only $4 \%$ of total demand (see Figure 10).

\subsubsection{Nuclear dominant}

In Sweden the major electricity demand is covered by nuclear and hydropower plants with $55 \%$ and $30 \%$ respectively (see Figures 6,9 ), while the biodiesel together with wind are covering $15 \%$ of total electricity demand and only the $5 \%$ is covered by fossil fuel. Having most of the electricity production by nuclear and hydro power plants and a not negligible contribution by biodiesel, makes Sweden a country with one of the major WF in EU, as can be seen in Figure10. From the period 2008 - 2012 Sweden produced 645.7 Twh electricity by hydro and nuclear sources. This represents about the $85 \%$ of total electricity production. This represented the $94.5 \%$ of total blue WF demand and $30 \%$ of total WF. Biodiesel and fossil fuel while covering $7 \%$ and $5 \%$ of total electricity demand, represented the $70 \%$ and $0.03 \%$ regarding the total WF. The last numbers clearly illustrate the incredibly large contribution to the WF by even a small fraction of biodiesel. 

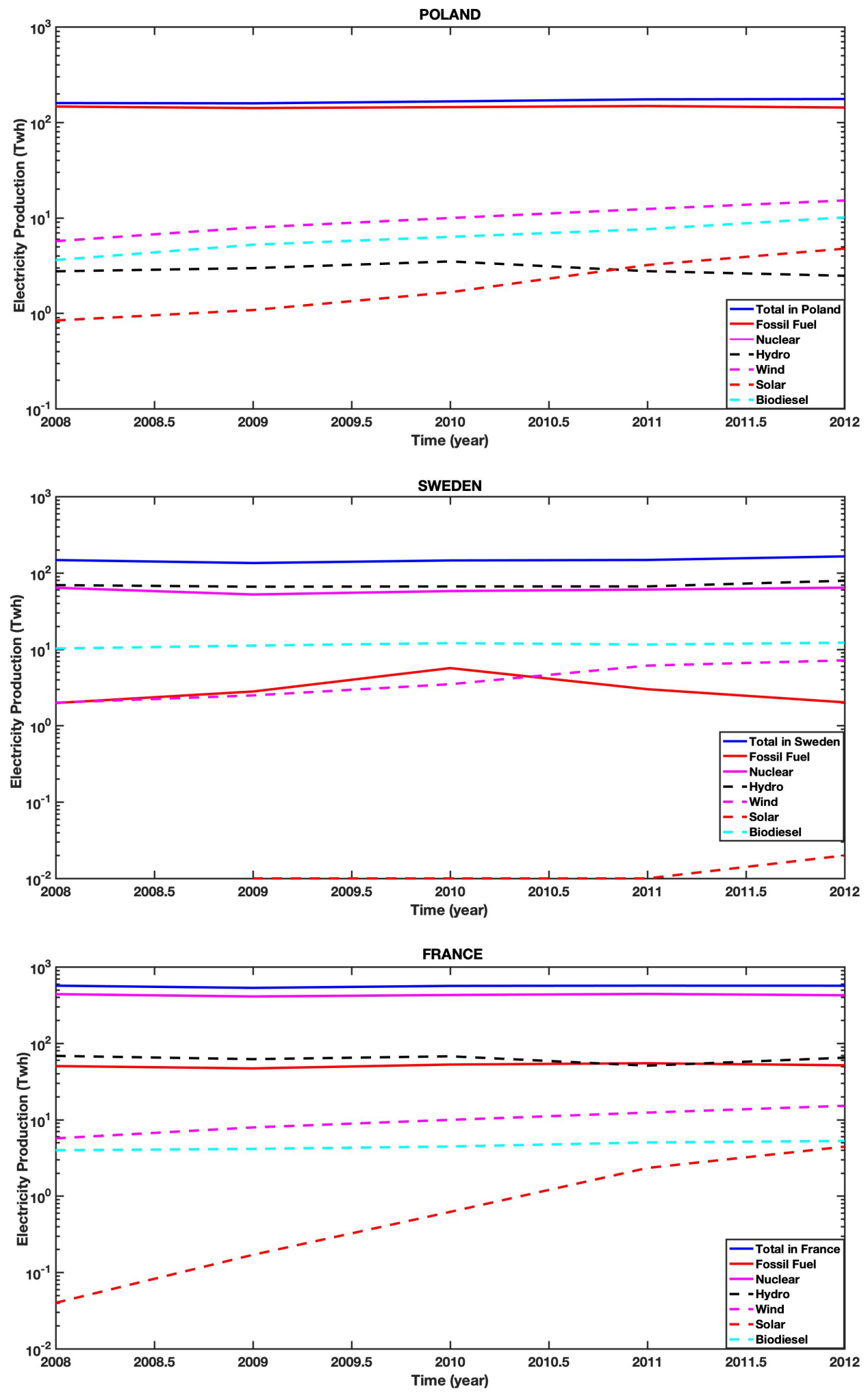

Figure 9: Electricity production per energy source of some EU countries (note the y-axis logarithmic scale). 

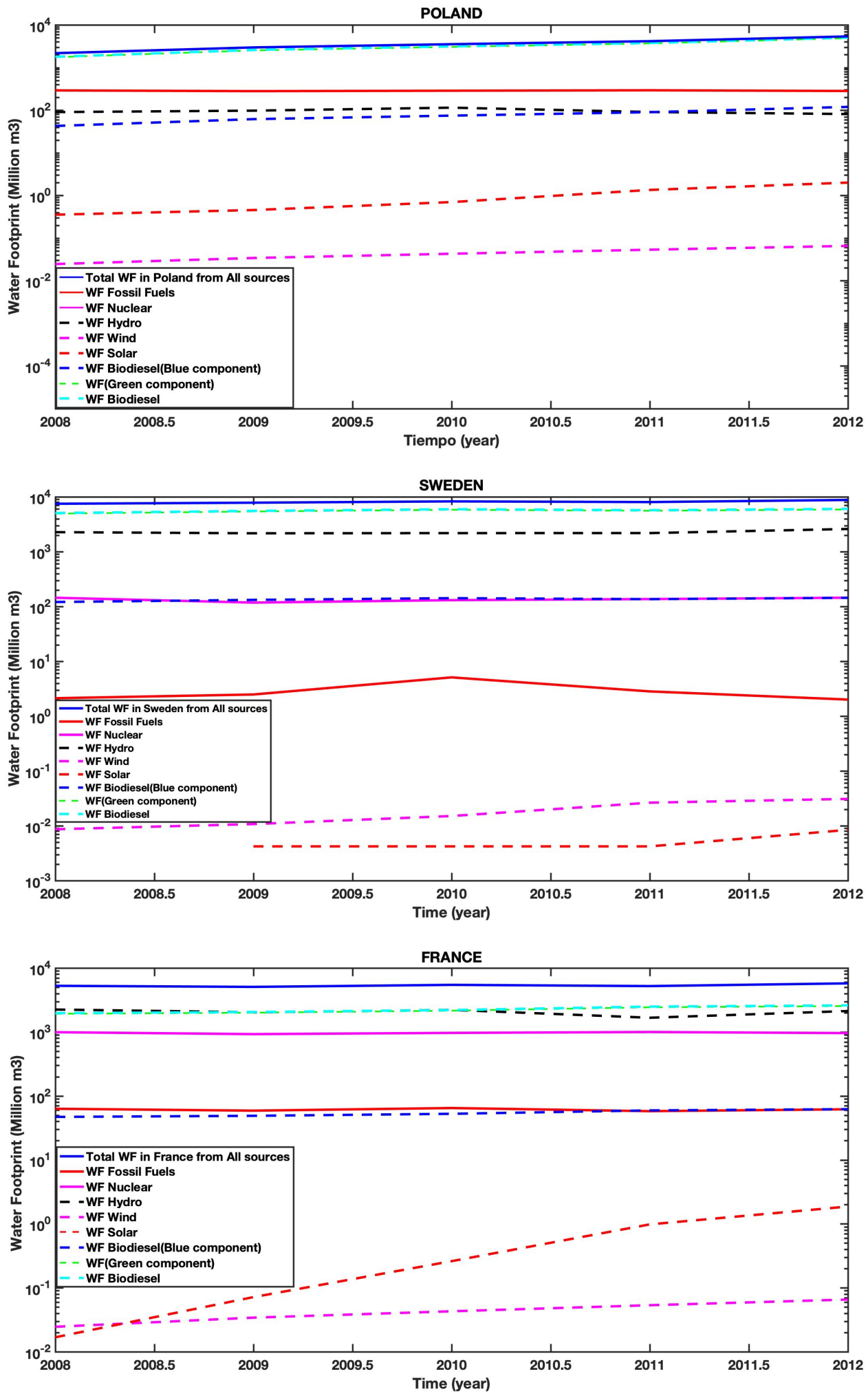

Figure 10: WF per energy source of some EU countries (note the y-axis logarithmic scale). 
France is a leader in the production of electricity through nuclear energy, which covers almost $72 \%$ of its total demand (the largest in the EU). Second and third dominant electricity productions are generated through hydropower and fossil fuel plants. Renewable energy sources like wind, solar and biodiesel show positive growing values with time (Figure 9). As nuclear is the dominant source of electricity production and it has significant WF values during fuel supply chain, construction and operation phases, its contribution to the total WF in France will be important. In particular, in the period between 2008-2012 the average nuclear energy produced was 429.1 Twh with 969 million $\mathrm{m}^{3}$, but this represents only the $18 \%$ of total WF. Wind and biodiesel are the second and third larger producers of electricity from renewable sources, but in terms of WF, they represent minimum and maximum cases (Figure 10). In fact, biodiesel together with hydro are the two sources that represent the largest contribution to total WF in France with about $40 \%$ weight each.

\begin{tabular}{|c|c|c|c|c|c|c|c|}
\hline Country & $\begin{array}{c}\text { Fossil } \\
\text { Fuel }\end{array}$ & Nuclear & $\begin{array}{c}\text { Hydro } \\
\text { power }\end{array}$ & Wind & Solar & Biodiesel & Total \\
\hline Sweden & 2.9075 & 134.778 & 2279.076 & 0.0183 & 0.0042 & 5663.034 & 8079.817 \\
\hline Portugal & 31.937 & 0 & 338.80 & 0.03623 & 0.09097 & 1229.715 & 1600.5792 \\
\hline Greece & 78.589 & 0 & 171.664 & 0.01266 & 0.21228 & 100.081 & 350.5589 \\
\hline Poland & 28.6214 & 0 & 94.756 & 0.04414 & 0.97128 & 3254.139 & 3378.531 \\
\hline France & 61.236 & 969.032 & 2057.343 & 0.04410 & 0.63938 & 2265.21 & 5353.504 \\
\hline Italy & 183.359 & 0 & 1618.79 & 0.03784 & 2.73274 & 3554.978 & 5359.897 \\
\hline
\end{tabular}

Table 4: The average WF expressed in million $\mathrm{m}^{3}$ for European countries for the period of 2008 - 2012 per energy source.

Table 4 summarises the WF results, per energy source, for the EU countries described in this section. From the table, it is very easy to see that Sweden and Greece represent the maximum and minimum extreme cases, respectively. This is a consequence of the huge (reduced) use of biodiesel in the electricity production by Sweden (Greece). However, according to the EU statistics database eurostat [19], Sweden is Europe's largest producer of renewable energy. As we have seen, this is absolutely not the case in terms of WF.

\section{Water Footprint and Electricity production in the region of Andalusia}

Using the database provided by the "Agencia Andaluza de la Energía" [20] we have carried out a systematic study about the WF in Andalusia region. The study includes the available information which comprises the time interval between 2000 and 2018 (the last two decades). This database distinguish only between renewable and non-renewable energy sources, and the available information is shown in Figure 11. 


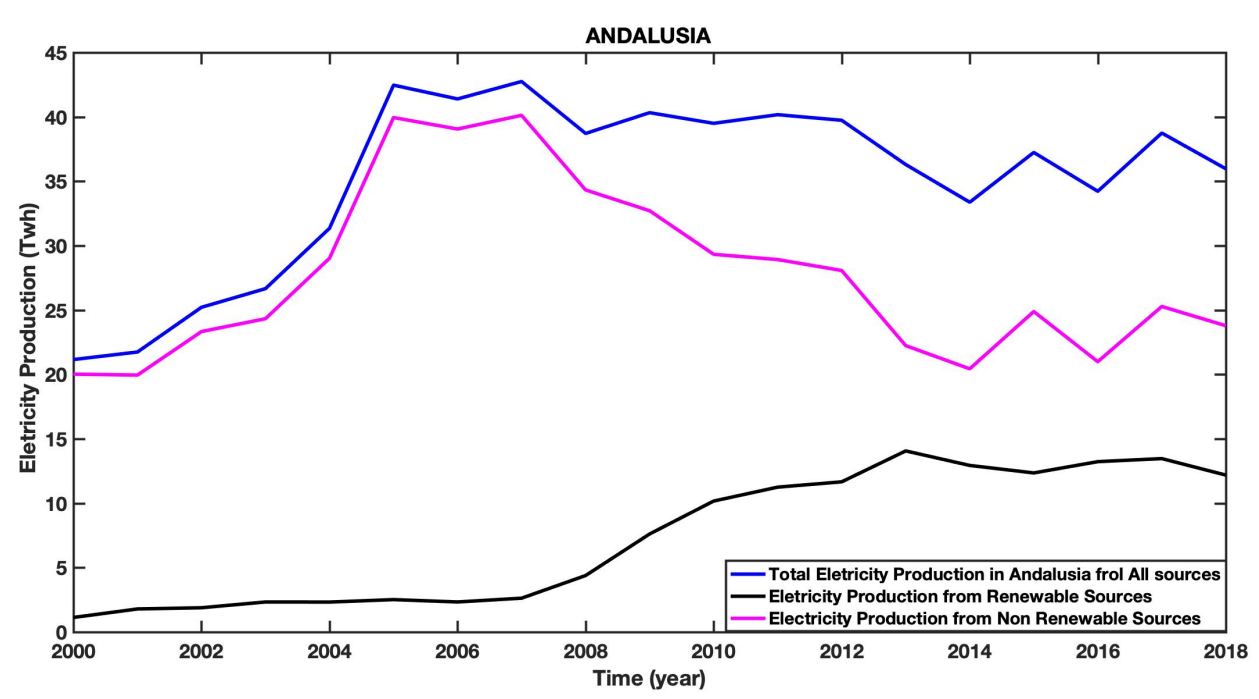

Figure 11: Electricity production in the region of Andalusia from renewable and nonrenewable energy sources in the time period 2000-2018 [20].

Andalusia region represents about the $13 \%$ of total electricity demand in Spain, and at the beginning of 21th century the production of electricity was mainly based on fossil fuel [21]. Around 2007 there was a drastic fall in the use of non-renewable energies, resulting in a reduction of about a $40 \%$ at present. This behaviour was accompanied by a gradual increase in the use of renewable energies for the electricity production, as can be seen in Figure 11. The same trend was observed for the case of Spain, as we described in Section 3.1.1. Likewise, we relate this fall to the global economic crisis and also to the environmental restrictions imposed by Europe at that time. All this had a positive impact on the reduction of carbon dioxide emissions $\left(\mathrm{CO}_{2}\right)$ in the province of Andalusia. The sector that contributes most to $\mathrm{CO}_{2}$ emissions in Andalusia is the production of electricity. As we saw earlier, in compliance with the Kyoto Protocol (1997), the European Union of 15 (EU-15) accepted the commitment to reduce its greenhouse gas emissions by $8 \%$ by the period 2008 - 2012. According to the annual publication of the "Consejería de Medio Ambiente y Ordenación del Territorio de la Junta de Andalucía" [22], $\mathrm{CO}_{2}$ emissions in the period 2005 - 2014 have fallen from 32.35 million tonnes to 22.46 million tonnes, representing a drop of around 30\%, which would be part of the drop of around $40 \%$ in electricity production from non-renewable sources mentioned above.

To calculate the total blue and green WF in Andalusia, as we have been doing in the previous sections, we would need the energy production information of each energy source. Due to the absence of this information (remember that for the case of Andalusia we only have available the energy generated by the total of renewable and total of nonrenewable sources), we have had to use an approximation. 


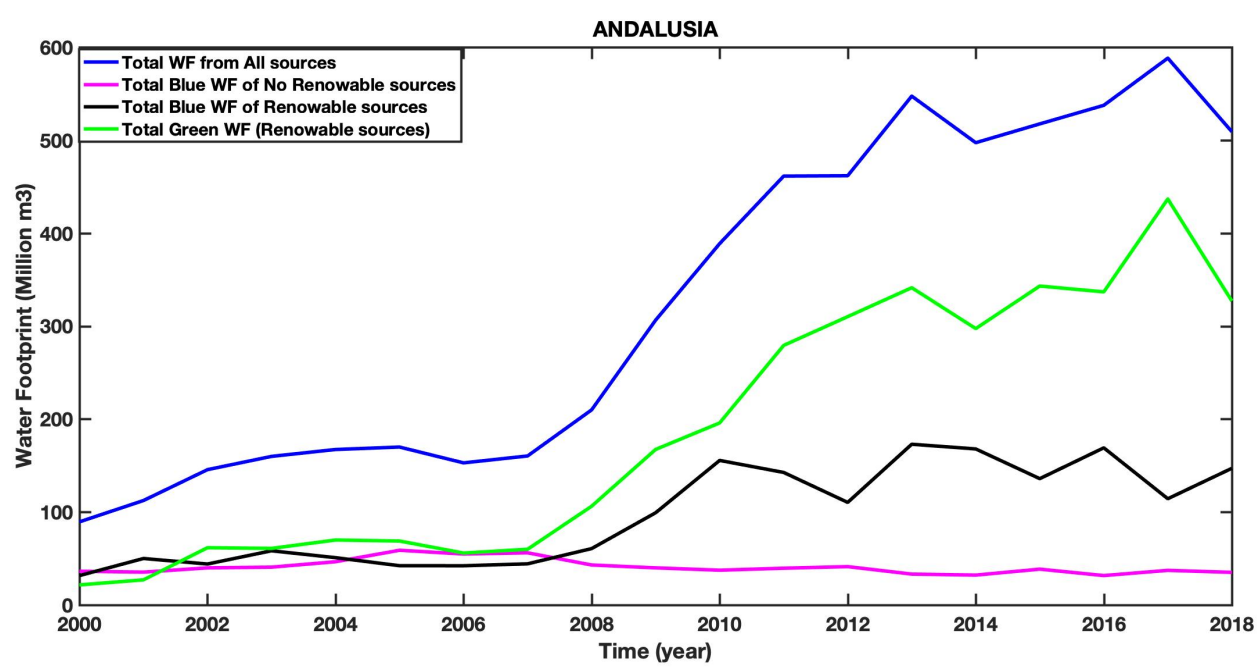

Figure 12: The blue and green WFs from the electricity production in the region of Andalusia.

In order to obtain the "grouped" WF of renewable and non-renewable energy sources in a realistic way, what we have assumed is that in Andalusia the relative weight of each of the renewable sources (i.e. hydro, wind, solar and biodiesel) and non-renewable sources (i.e. coal, oil, natural gas and nuclear) is the same as for the case of Spain in the same period of time. In that way, using the data by energy source in Spain (which are available and described in Section 3.1) we have calculated the relative weights, per energy source, shown in Table 5 that we will apply for the case of Andalusia. Thus, using the energies shown in Figure 11 we have been able to obtained the values of the WF for Andalusia, which are shown in Figure 12. Once more we see how renewable energies, while being subdominant in the production of electrical energy, end up being the main contribution to the total WF, basically driven by hydro and biodiesel sources. The average WF of non-renewable energy sources in Andalusia region represents the $1.4 \%$. On the other hand, WF from renewable sources in Andalusia represent the $8.6 \%$ of total WF demand in Spain.

As reported by [23], Andalusia is one of the leaders in the production of electricity through hydroelectric plants, which in turn, as we have seen, is one of the main producers of WF. According to our estimates of WF in Andalusia, hydroelectric plants account for $28 \%$ of total amount. On the other hand, one of the fastest growing forms of electricity production in the region has been biodiesel. According to the information provided by Ecologistas en accion, the region of Andalusia was the main one in the production of biodiesel in 2018, something that can be noticed in Figure 11, where we can see the increase of electricity production through renewable energy sources. This positive trend represents a rising development of green energy in Andalusia, but on the other hand it has its negative environmental effect in terms of water use, as it is increasing the total demand for WF. In a region like Andalusia, where the shortage of fresh water is a major problem, it becomes an issue particularly relevant. According to our calculations, electricity production through biodiesel in Andalusia would be covering $1 \%$ of the total electricity demand in the last two decades, while WF through this source would be $59 \%$ of the total WF in Andalusia. 


\begin{tabular}{|c|c|c|c|c|c|c|c|c|}
\hline Year & $\begin{array}{c}\text { Coal } \\
{[\%]}\end{array}$ & $\begin{array}{c}\text { Oil } \\
{[\%]}\end{array}$ & $\begin{array}{c}\text { Natural } \\
\text { Gas }[\%]\end{array}$ & $\begin{array}{c}\text { Nuclear } \\
{[\%]}\end{array}$ & $\begin{array}{c}\text { Hydro } \\
{[\%]}\end{array}$ & $\begin{array}{c}\text { Wind } \\
{[\%]}\end{array}$ & $\begin{array}{c}\text { Solar } \\
{[\%]}\end{array}$ & $\begin{array}{c}\text { Biodiesel } \\
{[\%]}\end{array}$ \\
\hline 2000 & 0.429 & 0.122 & 0.109 & 0.337 & 0.836 & 0.124 & 0.0002 & 0.039 \\
\hline 2001 & 0.386 & 0.135 & 0.128 & 0.350 & 0.839 & 0.129 & 0.0003 & 0.031 \\
\hline 2002 & 0.395 & 0.139 & 0.157 & 0.307 & 0.687 & 0.244 & 0.0005 & 0.067 \\
\hline 2003 & 0.373 & 0.120 & 0.196 & 0.309 & 0.741 & 0.204 & 0.0003 & 0.053 \\
\hline 2004 & 0.357 & 0.107 & 0.248 & 0.287 & 0.643 & 0.293 & 0.0003 & 0.062 \\
\hline 2005 & 0.329 & 0.1 & 0.329 & 0.24 & 0.490 & 0.451 & 0.001 & 0.056 \\
\hline 2006 & 0.276 & 0.098 & 0.376 & 0.248 & 0.532 & 0.415 & 0.002 & 0.049 \\
\hline 2007 & 0.301 & 0.076 & 0.393 & 0.228 & 0.496 & 0.448 & 0.008 & 0.047 \\
\hline 2008 & 0.197 & 0.073 & 0.490 & 0.239 & 0.402 & 0.507 & 0.039 & 0.050 \\
\hline 2009 & 0.166 & 0.089 & 0.499 & 0.244 & 0.379 & 0.496 & 0.078 & 0.045 \\
\hline 2010 & 0.127 & 0.083 & 0.477 & 0.311 & 0.450 & 0.438 & 0.071 & 0.039 \\
\hline 2011 & 0.217 & 0.072 & 0.423 & 0.285 & 0.366 & 0.477 & 0.104 & 0.051 \\
\hline 2012 & 0.269 & 0.074 & 0.358 & 0.297 & 0.266 & 0.546 & 0.132 & 0.054 \\
\hline 2013 & 0.237 & 0.081 & 0.342 & 0.337 & 0.355 & 0.481 & 0.113 & 0.050 \\
\hline 2014 & 0.269 & 0.086 & 0.290 & 0.352 & 0.376 & 0.455 & 0.119 & 0.047 \\
\hline 2015 & 0.288 & 0.096 & 0.294 & 0.320 & 0.312 & 0.491 & 0.138 & 0.057 \\
\hline 2016 & 0.220 & 0.102 & 0.321 & 0.355 & 0.368 & 0.452 & 0.126 & 0.052 \\
\hline 2017 & 0.2466 & 0.086 & 0.349 & 0.317 & 0.232 & 0.541 & 0.158 & 0.067 \\
\hline 2018 & 0.225 & 0.087 & 0.350 & 0.336 & 0.346 & 0.478 & 0.119 & 0.055 \\
\hline
\end{tabular}

Table 5: Fraction of the different energy sources contributing to the electricity production in Andalusia in terms of renewable and non-renewable. These numbers have been estimated assuming Spain data for the same time period. Note: Calculations have been made using MatLab package [12], shown in Appendix B.

\section{Water Footprint of the energy system in WWTP in the province of Granada}

\subsection{WWTP available data in Granada}

The research carried out in this section is based on information from six WWTP provided by the Diputacion Provincional de Granada, all located in the province of Granada. Table 6 shows the provided information, based on their typology, capacity (in equivalent inhabitants), flow rate of treated water (in $\mathrm{m}^{3}$ ) and electricity consummation (in Kwh).

However, the information provided from Diputacion Provincional de Granada was in some cases incomplete (Beas de Granada, Órgiva and Cañar) for the Flow Rate and Electricity Consume. In order to be able to perform our analysis in those cases, we had to make some approximations.

Figure 13 shows the available Flow Rate of WWTP for Beas de Granada and Cañar. As can be seen, for these two municipalities, the information for several months of the year is missing. We have approximated the missing data by the average Flow Rate of the year calculated with the available months. 
Regarding the Electrical Consume of WWTP, for the cases of Cañar and Órgiva, some information about the electricity provider company was missing. For them, the available information was the price list and provider company (Endesa), but not the amount of used energy. To extract the Electricity Consume (showed in Table 6) we have used the available light rate prices from Endesa: $0.150378 \mathrm{Kwh} /$ Eur and $0.162946 \mathrm{Kwh} /$ Eur for Cañar (year 2015) and Órgiva (year 2018), respectively. An example for the former is shown in Figure 14. In the Left you can see an electricity bill from El Valle in 2015 showing the light rate price. In the Right, the 2015 pay-list for Cañar is shown.

\begin{tabular}{|c|c|c|c|c|c|}
\hline Year & Municipality & Typology & $\begin{array}{c}\text { Population } \\
\text { Equivalent }\end{array}$ & $\begin{array}{c}\text { Flow Rate } \\
{\left[\mathrm{m}^{3}\right]}\end{array}$ & $\begin{array}{c}\text { Electricity } \\
\text { Consume } \\
{[\mathrm{Kwh}]}\end{array}$ \\
\hline 2018 & $\begin{array}{c}\text { Beas de } \\
\text { Granada }\end{array}$ & Trickling filter & 1092 & 167331.15 & 67209 \\
\hline 2018 & Orgiva & Trickling filter & 5460 & 344922.1 & 101975.5 \\
\hline 2015 & Cañar & $\begin{array}{c}\text { Sequencing batch } \\
\text { reactor (SBR) }\end{array}$ & 249 & 117201.82 & 17964.7 \\
\hline 2018 & El Valle & $\begin{array}{c}\text { Stahlermatic } \\
\text { Aerotor }\end{array}$ & 1130 & 107435 & 72445 \\
\hline 2018 & Gorafe & $\begin{array}{c}\text { Extended or } \\
\text { Prolonged aeration }\end{array}$ & 526 & 8164.14 & 20337 \\
\hline 2014 & Zafarraya & BioDiscs & 2146 & 142024 & 45770 \\
\hline
\end{tabular}

Table 6: Summary of all available information from Waste Water Treatment Plant in the province of Granada.

\subsection{Typology and energy requirements of the WWTP in the province of Granada}

WWTPs are electricity-intensive systems. In total, there are around 2533 WWTPs registered in Spain, where in the region of Andalusia alone there are 545, according to the publication in 2016 of the Ministerio de Medioambiente de la Junta de Andalucía, covering $21 \%$ of the total number of WWTPs registered in Spain [24]. These WWTPs cover the needs of a population of $7,118,859$ people, which is $87 \%$ of the total undistributed population of Andalusia. Of the total of 545 WWTPs, only 50 of them are installed in the province of Granada. In this section we have studied the Water Footprint of the energy system of 6 WWTPs (of the 50) whose information has been provided by the Diputacion Provincial De Granada.

The energy consumption in a WWTP varies according to the size of the plant, the pollutant load of the influent, the type of treatment and the technology used, so electricity consumption will vary from one to another. Table 6 contains the information about the sizes of the WWTPs in terms of their population equivalent, treatment methodology, annual flow rate and annual electricity consumption. 

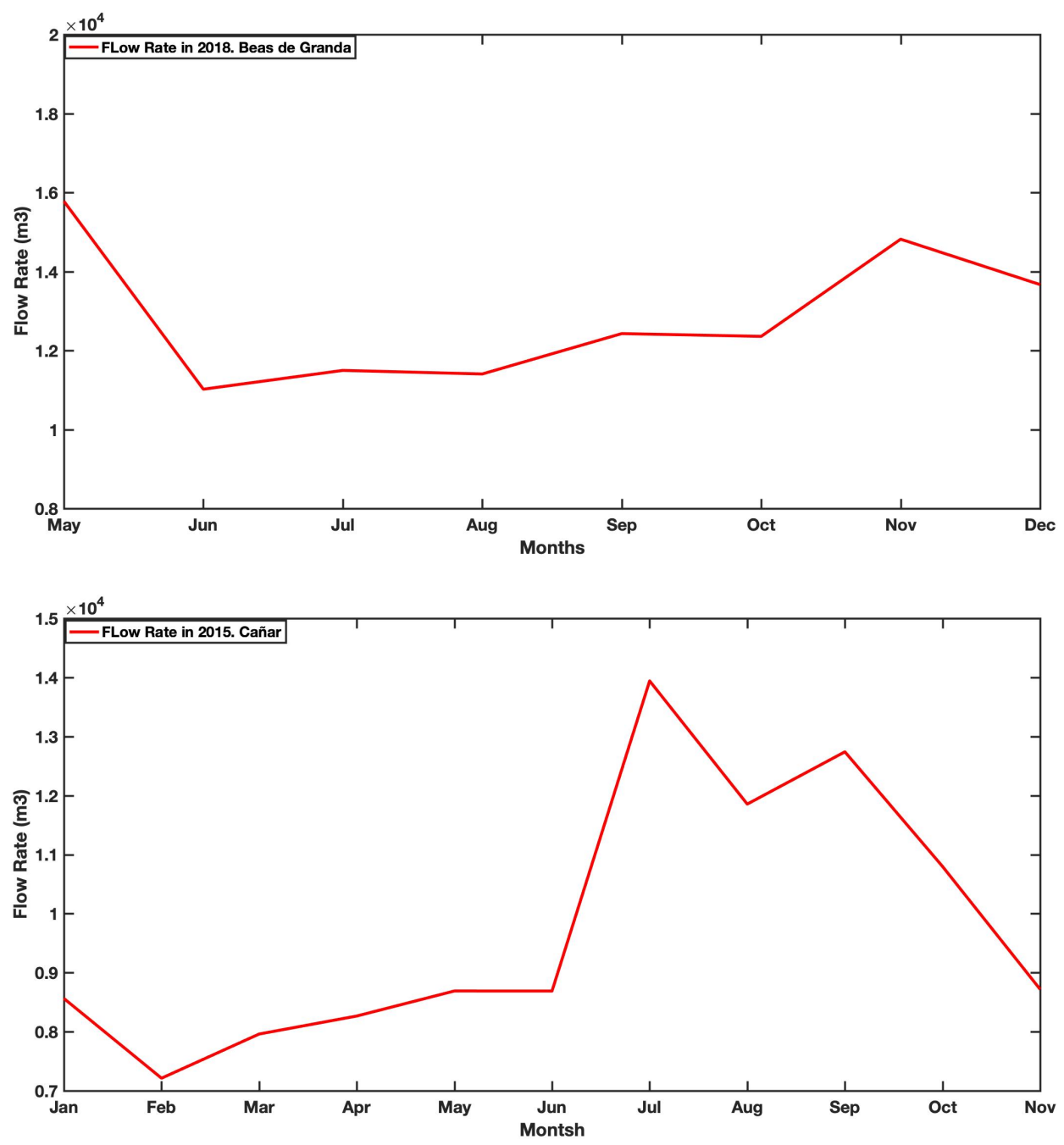

Figure 13: Top: Flow Rate of WWTP of Beas de Granada from May to December. Bottom: Flow Rate of WWTP of Cañar from January to November.

\section{Lendesal LUZ}

Endesa Energía, S.A. Unipersonal.

CIF A81948077.

C/Ribera del Loira, $n^{\circ} 6028042$ - Madrid.
Producto contratado: Tarifa Luz Enc № factura: P1M501 N0020560 Referencia: 085029610988/0040 Pecha emisión factura: 15/09/2015 (Detalle de la factura en el reverso)

\section{AYTO EL VALLE}

Facturación por energía consumida: es el resultado de multiplicar los kWh consumidos en el periodo de facturación por el término de energía contratado, que incluye el precio del término de energía del peaje de acceso. $603 \mathrm{kWh} \times 0,150378 \mathrm{Eur} / \mathrm{kWh}$

$1.695 \mathrm{kWh}$

En dicho importe, su facturación por peaje de acceso ha sida:

$603 \mathrm{kWh} \times 0,044027 \mathrm{Eur} / \mathrm{kWh}$

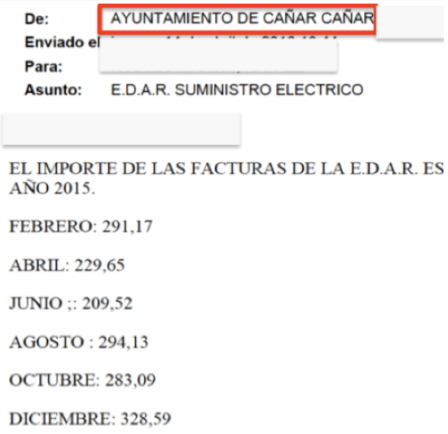

DICIEMBRE: 328,59

Figure 14: Example of electricity bill of WWTP for El Valle, and the WWTP price list of Cañar. 
In Beas de Granada and Órgiva villages is used a WWTP typology of Trickling filters for treating wastewater. Trickling filters (TF's) are used to remove organic matter from wastewater. It is an aerobic treatment system that utilises microorganisms attached to a medium to remove organic matter from wastewater. TFs are a secondary treatment after a primary setting process, after the waste water flew through septic tanks or pre treatment. In general it can consists of a fixed bed of rocks, coke, gravel, slag, polyurethane foam, sphagnum peat moss, over which sewage or other wastewater flows downward and causes a layer of microbial slime (biofilm) to grow, covering the bed of media. Aerobic conditions are maintained by splashing, diffusion, and either by forced-air flowing through the bed or natural convection of air if the filter medium is porous. From the point of view of electricity consumption, this type of WWTP have high energy efficiency, comparable with activated sludge WWTP. Practically a pump and a hydraulic distributor are all the electro-mechanical equipment needed for a WWTP of this type, which is making this plants energy effective. This type of WWTP are suitable for small towns and have high effluent quality in terms of Biochemical Oxygen Demand (BOD) and suspended solids removal.

The WWTP installed in Cañar village is using Sequencing Batch Reactor(SBR) technology for treating the water. The SBR is an optimized variant of conventional activated sludge technology. It is based on the use of a single reactor that operates in a sequential batch mode. The SBR system consists of at least four cyclic processes: filling, aeration, anoxic stage, decantation and emptying of both effluent and sludge. One of the main advantages of this type of WWTP is the compact installed size of plant and low costs. They are very suitable for small town with relatively small population. The SBR does not require high electricity resources, even though their system require the aeration stage. This is directly related with the treatment method, which requires a short aeration and rest phases alternate in a controlled cleaning process. The BOD removal efficiency is generally 85 to $90 \%$.

In El Valle the installed WWTP is working with the Stahlermatic-Aerotor (STMAeromotor) technology of treating wastewater [24]. The STM-Aeromotor is designed as a rotor equipped with pipes created by media-discs. As soon as a pipe of the rotor emerges above water level during rotation, the mixed liquor inside the pipes flows out. By this it is firstly aerated at the spillway. The pipe will then be filled with atmospheric air necessary oxygen for the fixed film dissolves on the wet surfaces of the media discs with every rotation, the STM-Aerotor captures atmospheric air, draws it down into mixed liquor in a steel or concrete basin, and slowly releases it as course bubble aeration. During the rotation, additional cascade aeration elevates the dissolved oxygen in the upper layer of the basin. The combination of the slow rotation of the STM-Aerotor, the intense air release, and the addition of a peripheral mixing paddle ensure a thoroughly mixed system. In addition, the STM-Aerotor includes a large surface area for fixed film growth (biofilm). The interior and exterior of the special polypropylene discs provide the perfect environment for a variety of attached growth organisms. By rotating the rotor by a motor above water level, surface air is captured by the special design of the fixed film media and consequently the microorganisms in the basin are supplied with oxygen. This way to remove Biological Nutrient (BNR) requires relatively high electricity demand, which is related with the slowly rotated motor. Although this system does not require specific blowers or diffusers for the aeration system, the electricity demand required is significantly high. 
In Gorafe the WWTP is working with extended or prolonged aeration system. The extended aeration process is one modification of the activated sludge process which provides biological treatment for the removal of biodegradable organic wastes under aerobic conditions. Air may be supplied by mechanical or diffused aeration to provide the oxygen required to sustain the aerobic biological process. Diffused air is introduced into the aeration tank, this provides the proper environment for the development of aerobic bacteria. These bacteria thrive on the materials contained in the wastewater. Mixing must be provided by aeration or mechanical means to maintain the microbial organisms in contact with the dissolved organics, which depends on the methodology will increase or decrease the energy demand of WWTP. In the extended aeration process, the raw sewage goes straight to the aeration tank for treatment. The whole process is aerobic, where there is no need of Primary Settling Tank. Extended aeration package plants consist of a steel tank that is compartmentalized into flow equalization, aeration, clarification, disinfection, and aerated sludge holding/digestion segments. These extended aeration plants are providing excellent Biochemical Oxygen Demand and Total Suspended Solids (TSS) removal efficiency. Extended aeration is preferred for relatively small waste loads. In the case of Gorafe the annual flow rate is $8164.14 \mathrm{~m}^{3}$, the minimum value on Table 6 .

In the village of Zafarraya the installed methodology for the treatment of wastewater is through Bio-disk. Bio-disk is a natural biological process for the treatment of wastewater based on the principle of rotating biological contactors (RBC's). This process has many inherent operating characteristics that make it suitable for the treatment of domestic or commercial wastewater. The discs remain semi-submerged in the water so that when they rotate they put the biofilm in contact with the water and the air in an alternative way. Biofilms, which are biological growths of biomass that become attached to the bio-discs, digest the organic materials in the wastewater. The aeration system does not require special blowers, which makes this waste water treatment system energy efficient. The aeration is provided by the rotating action, which exposes the bio-discs to the air after contact with wastewater. The threaded effluent then flows to a final settlement tank where dead bacterias and small particles settle to the bottom. The cleaned effluent then discharges through the outlet. The discs themselves treat the sewage effluent after it has passed through a Primary Settlement Tank. The primary settlements tank settles the solids which form of a sludge in the bottom of the tank. The rotation is achieved via a motor, which is manly required machine of electricity.

\subsection{Water Footprint and Used Fresh Water of WWTP in the province of Granada}

According to the physical description information of the WWTPs showed in Table 6, the ratio of treated water $\left(\mathrm{m}^{3}\right)$ to consumed electricity (Kwh), which is known as "ratio of energy consumption", was calculated and values are shown in Table 7. 


\begin{tabular}{|c|c|c|}
\hline Year & Municipality & $\begin{array}{c}\text { Energy-consumption } \\
\text { ratio }\left(\mathrm{Kwh} / \mathrm{m}^{3}\right)\end{array}$ \\
\hline 2018 & Beas de Granada & 0.4016 \\
\hline 2018 & Órgiva & 0.2956 \\
\hline 2015 & Cañar & 0.15097 \\
\hline 2018 & El Valle & 0.6743 \\
\hline 2018 & Gorafe & 2.491 \\
\hline 2014 & Zafarraya & 0.322 \\
\hline
\end{tabular}

Table 7: Amount of Kwh of consumed electricity per $1 \mathrm{~m}^{3}$ of treated water for the WWTPs under study in Granada ("Ratio" in the table).

The energy requirements for WWTPs depend on the size and type of the treatment process employed, which typically requires about $60-70 \%$ of the total energy demand in the plant. As shown in Table 7 the highest ratio of electrical energy consumption per volume of treated water is detected in the WWTP installed in the village of Gorafe, where the treatment process is carried out by extended or prolonged aeration which, as we have described above, is a modification of the activated sludge process. The value of this ratio calculated from the data supplied by the Diputación Provincial de Granada is $2.491 \mathrm{Kwh} / \mathrm{m}^{3}$. This value is quite similar to the value obtained in [25] where 17 activated sludge WWTPs were studied in Greece and reported a value in the range 0.128 $-2.280 \mathrm{Kwh} / \mathrm{m}^{3}$.

The smaller WWTPs with significantly smaller treated flow rate per day $\left(\mathrm{m}^{3} /\right.$ day) are characterised by high energy consumption compared to relatively larger-scale WWTPs. Although small-scale wastewater treatment plants have a simplified configuration in wastewater and sludge handling processes, the unit energy consumption is higher than that of larger wastewater treatment plants due to less frequent optimisations. Multiple studies showing this behavior are described in [26]. The same trend has been observed for the WWTPs in the province of Granada that we have analyzed. In Table 8 we can see how energy consumption decreases substantially when the scale of the plant (flow rate per day) increases. For example, in the two extreme cases we would have daily flows of $24.9 \mathrm{~m}^{3}$ / day and $948.9 \mathrm{~m}^{3} /$ day which would correspond with energy consumptions of $2.49 \mathrm{Kwh} / \mathrm{m}^{3}$ and $0.29 \mathrm{Kwh} / \mathrm{m}^{3}$ for Gorafe and Órgiva, respectively.

\begin{tabular}{|c|c|c|}
\hline Municipality & $\begin{array}{c}\text { Energy-consumption } \\
\text { ratio }\left(\mathrm{Kwh} / \mathrm{m}^{3}\right)\end{array}$ & $\begin{array}{c}\text { Flow Rate } \\
\left(\mathrm{m}^{3} / \text { day }\right)\end{array}$ \\
\hline Beas de Granada & 0.4016 & 457.41 \\
\hline Órgiva & 0.2956 & 948.9 \\
\hline Cañar & 0.15097 & 328.6 \\
\hline El Valle & 0.6743 & 328.9 \\
\hline Gorafe & 2.491 & 24.9 \\
\hline Zafarraya & 0.322 & 463.99 \\
\hline
\end{tabular}

Table 8: The unit of energy consumption of the WWTPs with respect to the flow rate. 

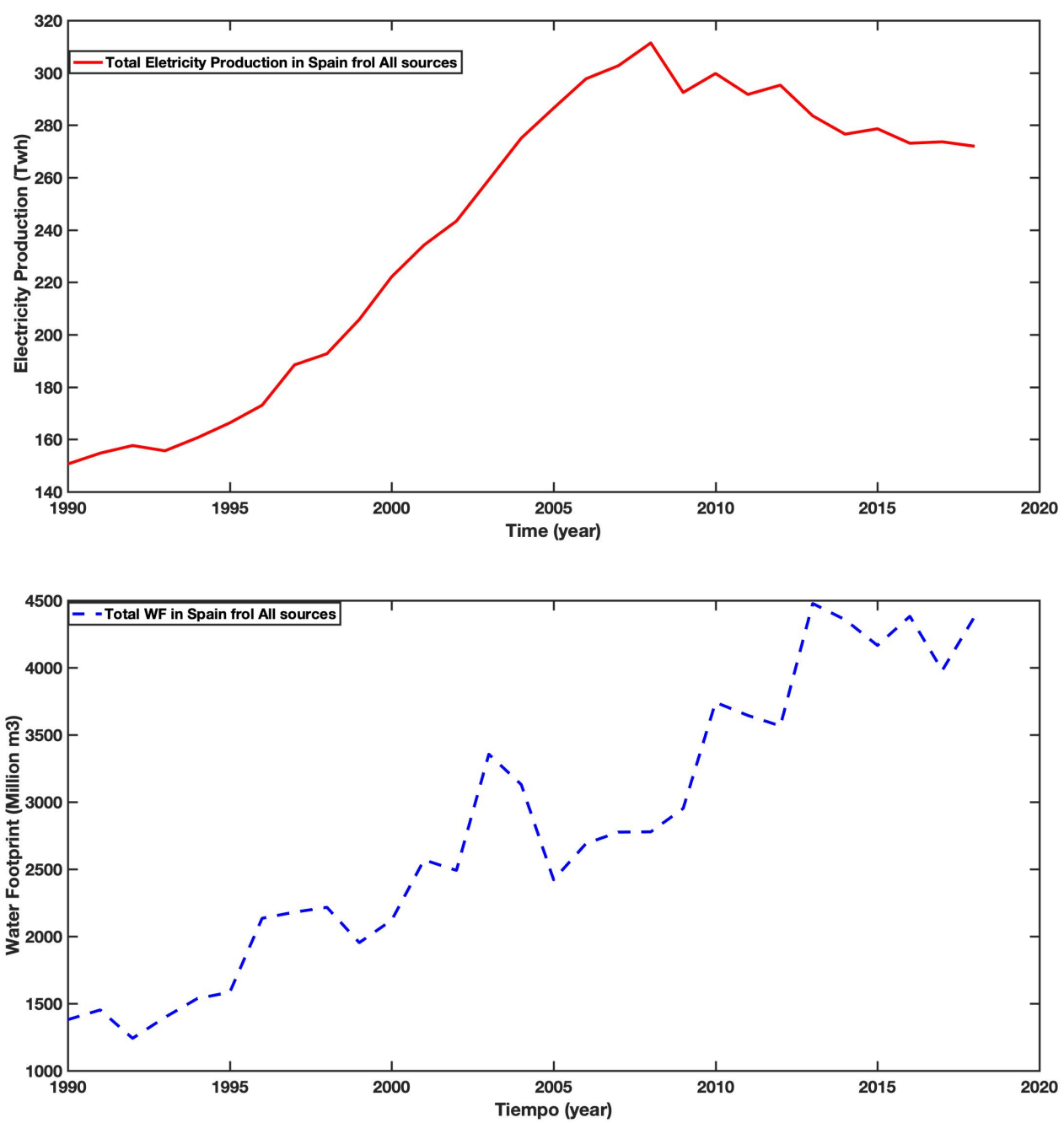

Figure 15: Total electricity production (Top) and total WF (Bottom) in Spain from the period 1990 - 2018.

The water-energy nexus is the relationship between how much water is used for energy production, and how much energy is used to collect, clean, move, store, and dispose of water (and wastewater). In fact, the concepts of Water Footprint and Used Fresh Water, although interesting in themselves, were invented to clarify this nexus.

Total electricity generation over the last three decades in Spain has increased by almost a factor $\times 2$. Taking into account all renewable and non-renewable energy sources together, its value has risen from 150.6 TWh to 271.9 TWh over that period (Figure 15Top). In Section 3.1 we also calculated the blue and green WF corresponding to this electricity generation. As we know, both magnitudes (produced energy and water footprint) present a linear relationship, so that the WF has experienced its corresponding growth, as shown in Figure 15-Bottom. The large fluctuations with time observed for the total WF is the results of the variation with time of the relative weights of the different energy sources (see Table 5), that are associated with quite different WFs (see Table 1). 
Finally, to answer our initial question"How much fresh water do we use to treat the water?", the new term Used Fresh Water (UFW) was introduced. It represents the amount of fresh water that was used in the energy production phase (described by the WF calculations) and expressed in $\mathrm{m}^{3} / \mathrm{Kwh}$, related to the total energy consumed per volume of treated water in WWTP expressed in $\mathrm{Kwh} / \mathrm{m}^{3}$ (described by the unit of energy consumption).

We have obtained the amount of fresh water used in the energy production in Spain by computing the ratio between the data shown in the bottom and top panels of Figure 15. Results are shown in Figure 16. The ratio of the average blue and green WF $\left(\mathrm{m}^{3}\right)$ per unit of generated electricity is $0.01139 \mathrm{~m}^{3} / \mathrm{Kwh}$ (or $11.39 \mathrm{~L} / \mathrm{Kwh}$ ), showing an increase of about a factor $\times 1.5$ from 1990 until 2018, varying from $9 \mathrm{~L} / \mathrm{Kwh}$ to $16 \mathrm{~L} / \mathrm{Kwh}$ respectively.

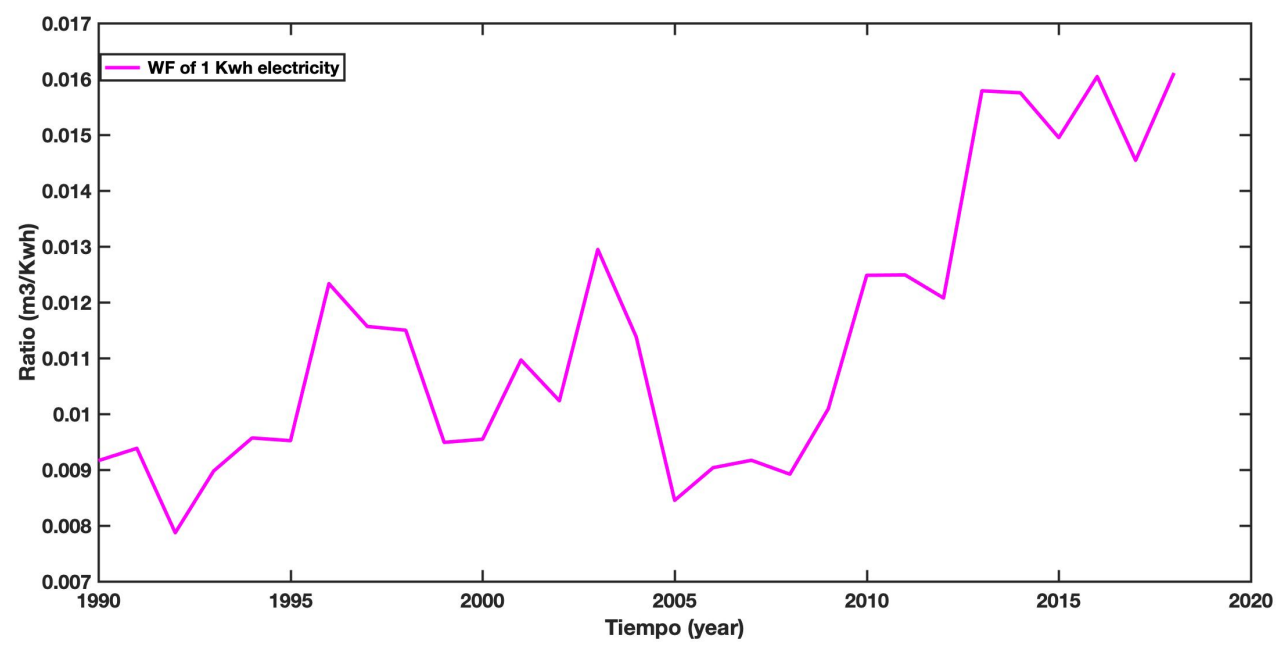

Figure 16: The ratio of blue and green WF per total produced electricity in Spain during the period 1990- 2018

To calculate the UFW values for the different WWTPs studied in the Granada region I have used the unit of energy consumed described in Table 8 together with the values of WF per unit of energy generated shown in Figure 16 (for the relevant years where data for the 6 WWTPs is available). The obtained results are shown in Table 9. Each number on the table, expressed in $\mathrm{m}^{3} / \mathrm{m}^{3}$, represents the amount of fresh water (including both blue and green WF) that was needed to treat $1 \mathrm{~m}^{3}$ of waste water in the WWTPs. From the values in the table, which are all at the percent level and below, it can be concluded that the waste of fresh water compared to the volume of treated water is negligible. 


\begin{tabular}{|c|c|c|}
\hline Year & Municipality & UFW $\left(\mathrm{m}^{3} / \mathrm{m}^{3}\right)$ \\
\hline 2018 & Beas de Granada & 0.0065 \\
\hline 2018 & Órgiva & 0.0048 \\
\hline 2015 & Cañar & 0.0022 \\
\hline 2018 & El Valle & 0.0109 \\
\hline 2018 & Gorafe & 0.0401 \\
\hline 2014 & Zafarraya & 0.0051 \\
\hline
\end{tabular}

Table 9: Used Fresh Water expressed in $\mathrm{m}^{3}$ of fresh water (from WF) per $\mathrm{m}^{3}$ of treated water for the 6 WWTPs under study in the province of Granada.

\section{Summary and conclusions}

In this Master's Thesis we have studied in detail the Water Footprint associated with the production of electricity for different energy sources, renewable and non-renewable, in the last decades. Although our main focus has been Spain, and the province of Granada, we have extended our studies to other countries and regions, in order to have a better understanding of the global picture. The main conclusions of our study are summarised below.

- In Spain, the electricity production is still dominated by non-renewable energy sources, nuclear, with coal(decreasing) and since recently natural-gas (increasing), representing similar contributions at the end of the period under study (2018). However, in recent years renewable alternatives are gaining in importance. This has been particularly true for the case of wind energy, that nowadays represent the larger contribution (18.7\%) above hydro (13.5\%) among the renewable group. If we focus in the WF associated to each energy source the situation changes drastically. Biodiesel, which represents a growing but marginal contribution over time to total electricity production $(\sim 2.2 \%)$, makes by far the largest contribution to WF, with over $65 \%$ of the total. The opposite situation is represented by wind energy, which presents the minimum WF $(0.005 \%)$ while having one of the largest energy production. It is worth to mention that the second energy source with better energy-production $(21.3 \%)$ and WF $(0.64 \%)$ balance is natural-gas.

- Related to greenhouse gas emissions, Sweden is the EU's leading country in terms of minimum emissions. But our WF studies have shown that this does not necessarily mean that it is the most environmentally friendly. According to our calculations, biodiesel in Sweden is the third electricity source producer, but in terms of WF it contributes to about the $70 \%$ of the total $\left(5663\right.$ million $\mathrm{m}^{3}$ from biodiesel per year). Furthermore, this represents a bit more than the total WF in countries like Italy (5360 million $\mathrm{m}^{3}$ total per year) and France ( 5354 million $\mathrm{m}^{3}$ total per year), which are the second and third in maximum WF among the EU countries we have studied. 
- The region of Andalusia shows the same trend of decreasing (increasing) contribution to electricity production from non-renewable (renewable) sources. It represents $\sim 13 \%$ of total electricity and $\sim 10 \%$ of total WF demand in Spain. The largest contribution to total WF comes again from the use of biodiesel, representing around $57 \%$ of total WF. Andalusia is a large consumer of biodiesel (first in Spain in 2018) with the benefits it brings to greenhouse gas emissions, but the damage to WF. In an increasingly dry region like Andalusia, these last points become very relevant and must be seriously addressed and rethought.

- We have studied the ratio of energy consumption (i.e. amount consumed electricity per $\mathrm{m}^{3}$ of treated water) for a sample of six WWTPs in Granada, based on their physical descriptions. The smaller WWTPs with significantly smaller treated flow rate per day $\left(\mathrm{m}^{3} /\right.$ day) are typically characterised by high energy consumption compared to relatively larger-scale WWTPs. This is what we have found in our sample under study, where we got the highest $\left(2.492 \mathrm{Kwh} / \mathrm{m}^{3}\right)$ and lowest $\left(0.151 \mathrm{Kwh} / \mathrm{m}^{3}\right)$ ratios for the installations in Gorafe $\left(24.9 \mathrm{~m}^{3} /\right.$ day $)$ and Cañar $\left(328.6 \mathrm{~m}^{3} /\right.$ day $)$, respectively, which is directly related with the installed treated water system and flow rate in each case.

- We used the ratio of energy consumed together with our WF calculations to obtain the values of the Used Fresh Water for the different WWTPs under study (with different types and sizes) in the region of Granada. From our studies we obtained that the waste of fresh water compared to the volume of treated water in a WWTP is very small (in the range $[0.0022-0.04] \mathrm{m}^{3} / \mathrm{m}^{3}$, values at the level of a few percent and well below). This result reinforces the idea of the importance of wastewater treatment and quantifies the efficiencies of different types of WWTPs, in terms only of water.

- All the previous points allow us to think about how to achieve even more efficient WWTPs, from the point of view of fresh water consumption. Here are some ideas/thoughts. In the case of the plants studied in Granada, their relatively small size would allow them to become self-sufficient from an energy point of view, without major technological complications, for example by installing a wind power plant, if geolocation permits, or through the use of photovoltaic solar panels. Thus, assuming a $100 \%$ wind (solar) power supply for our Gorafe plant, which is the least efficient (in relation to water use) with a UFW value of $4 \times 10^{-2} \mathrm{~m}^{3} / \mathrm{m}^{3}$ we would obtain a new UFW value of $1.08 \times 10^{-5} \mathrm{~m}^{3} / \mathrm{m}^{3}\left(1.05 \times 10^{-3} \mathrm{~m}^{3} / \mathrm{m}^{3}\right)$, which would result an improvement in the water use optimization of about a factor $\times 3700$ $(\times 38)$. In terms of water liters per year (L/year), a plant like Gorafe's wastes the amount of $365000 \mathrm{~L} /$ year, while a wind (solar) supplied plant would only waste $99 \mathrm{~L} /$ year $(9600 \mathrm{~L} /$ year). On the other side, some studies showed that for plants with a flow rate in the order of $500 \times 10^{3} \mathrm{~m}^{3}$ / day (significantly larger than the ones under study), a good energy audit focused on the main sub-consumers such as the piping system, the aeration system, and other more secondary ones such as the control system and the building's lighting, can decrease the total energy requirements by $20-30 \%$ [27]. 


\section{References}

[1] "Directive 2000/60/EC of the European Parliament and of the Council of 23 October 2000 establishing a framework for Community action in the field of water policy ." https://eur-lex.europa.eu/legal-content/EN/TXT/?uri=celex\% 3A32000L0060.

[2] "Directiva 2000/60/CE del Parlamento Europeo y del Consejo, de 23 de octubre de 2000, por la que se establece un marco comunitario de actuación en el ámbito de la política de aguas. ." https://www.boe.es/buscar/doc.php?id= DOUE-L-2000-82524.

[3] A. C. Delgado, "La evolución de la depuración de las aguas residuales urbanas en españa." http://hispagua.cedex.es/sites/default/files/hispagua_ articulo/Ingcivil/P-009-020.pdf, 2012.

[4] "Plan de calidad de aguas 2007-2015." https://www.miteco.gob.es/es/agua/ planes-y-estrategias/, 2015.

[5] "Data \& statistics - international energy agency." https://www.iea.org/ data-and-statistics? country=SPAIN\&fuel=Energy\%20supply\&indicator= CoalProdByType, 2020.

[6] P. W. G.-L. Mesfin M. Mekonnen and A. Y. Hoekstra, "The consumptive water footprint of electricity and heat a global assessment," Environmental Science Water Research Technology, March 2015.

[7] J. F. S. R. J. H. Davy Vanham, Hrvoje Medarac and D. Magagna2, “The consumptive water footprint of the european union energy sector," Environmental Research Letters, October 2019.

[8] G. H. J Macknick, R Newmark and K. C. Hallett, "Operational water consumption and withdrawal factors for electricity generating technologies: a review of existing literature," Environmental Research Letters, Volume 7, Number 4, December 2012.

[9] D. M. Pier Paolo Miglietta and F. D. Leo, "The water footprint assessment of electricity production: An overview of the economic-water-energy nexus in italy," Sustainability, January 2018.

[10] "Energy statistical country datasheets." https://rb.gy/apnbao, 2020.

[11] "España lidera la importación de carbón del extranjero después de cerrar todas sus minas." https://cutt.ly/4hahzlr, 2019.

[12] "Matlab programming language." https://www.mathworks.com/products/ matlab.html, 2018.

[13] “Greenhouse gas." https://en.wikipedia.org/wiki/Greenhouse_gas, 2019.

[14] “Aee presenta el anuario eólico 2020: análisis de la situación de la energía eólica en españa y en el mundo." shorturl. at/itwNo, 2020. 
[15] P. G.-L. A. H. T. van der Meer, "Water footprint of bio-energy and other primary energy carriers," Value of Water, March 2008.

[16] A. Y. H. Winnie Gerbens-Leenes and T. H. van der Meer, "The water footprint of bioenergy," PNAS, June 2009.

[17] Eurostat, "Shedding light on energy in the eu," Value of Water, April 2018.

[18] "Rpoland: $\mathrm{Co}_{2}$ country profile." https://ourworldindata.org/co2/country/ poland? country= POL, 2020.

[19] "Renewable energy statistics." https://ec.europa.eu/eurostat/ statistics-explained/index.php/Renewable_energy_statistics, 2018.

[20] "Agencia andaluza de la energia." http://www. agenciaandaluzadelaenergia.es/ info-web/principalController, 2020.

[21] "Agencia adaluza de la energia." https://www.agenciaandaluzadelaenergia.es/ sites/default/files/Documentos/datos_energeticos_2017.pdf, 2017.

[22] "La aplicación del régimen del comercio de derechos de emisión de gases de efecto invernadero en andalucía." http://www.agenciaandaluzadelaenergia.es/ info-web/principalController, 2020.

[23] "Plan de energias renovalbles en españa 2005 - 2010." https : //www. mincotur.gob. es/Publicaciones/OtrasPublicaciones/70Segundaparte.pdf, 2005.

[24] "Depuración e infraestructuras hidráulicas." http://www.juntadeandalucia. es/medioambiente/site/ima/menuitem.5893969315ab596f7bbe6c6f5510e1ca/ ?vgnextoid=fd87f024849cf510VgnVCM2000000624e50aRCRD\&vgnextchannel= 416261d298c7f510VgnVCM2000000624e50aRCRD\&lr=lang_es, 2016.

[25] A. M. Alexandra Siatou and P. Gikas, "Energy consumption and internal distribution in activated sludge wastewater treatment plants of greece," Water, April 2020.

[26] W. Z. T. . M. S. Khum Gurung, “Unit energy consumption as benchmark to select energy positive retrofitting strategies for finnish wastewater treatment plants (wwtps): a case study of mikkeli wwtp," PNAS, June 2018.

[27] Y. Z. Olumide Wesley Awe, Ranbin Liu, "Analysis of energy consumption and saving in wastewater treatment plant: Case study from ireland," Journal of Water Sustainability 2, June 2016.

[28] "Comparison of lifecycle greenhouse gas emissions of various electricity generation sources." http://www.world-nuclear.org/uploadedFiles/org/WNA/ Publications/Working_Group_Reports/comparison_of_lifecycle.pdf, 2019.

[29] R. Soley, “Bioenergía en españa: ¿es realmente una alternativa?," Bird Life Europe y Transport and Environment, December 2019.

[30] “Edar de fuentes de andalucia." https://www.iagua.es/data/infraestructuras/ edar, 2019. 
[31] R. E. D. ESPAÑA, "Renewable energy in the spanish electricity system," RED ELÉCTRICA DE ESPAÑA, June 2018.

[32] "Ministerio de agricultura y pesca, alimentación y medio ambiente." http://www . juntadeandalucia.es/medioambiente/portal_web/rediam/ indicadores/2017/EN01_2017.pdf, 2018.

[33] "Emisiones de gases de efecto invernadero." shorturl. at/ntAFY, 2018.

\section{A Appendix}

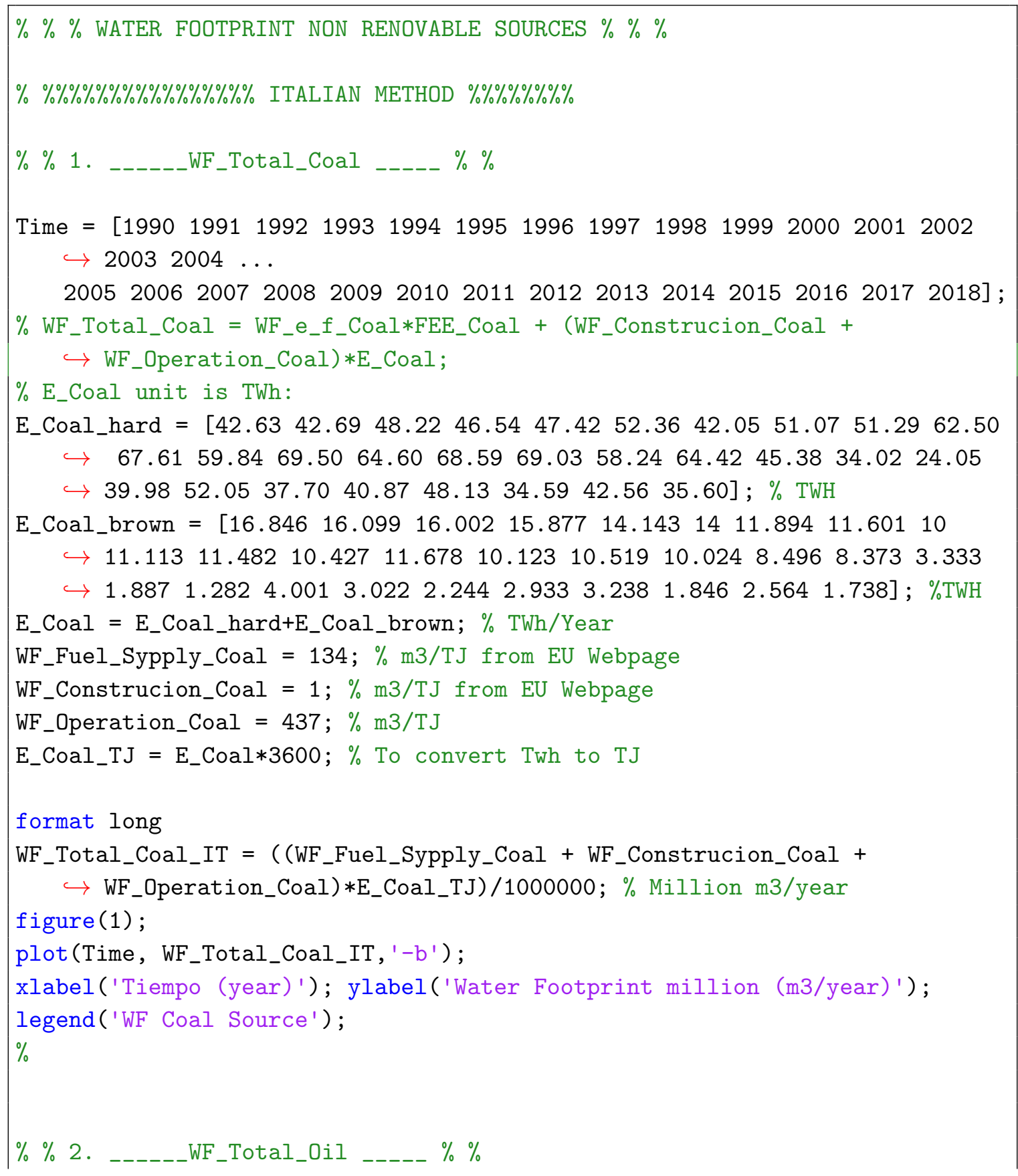




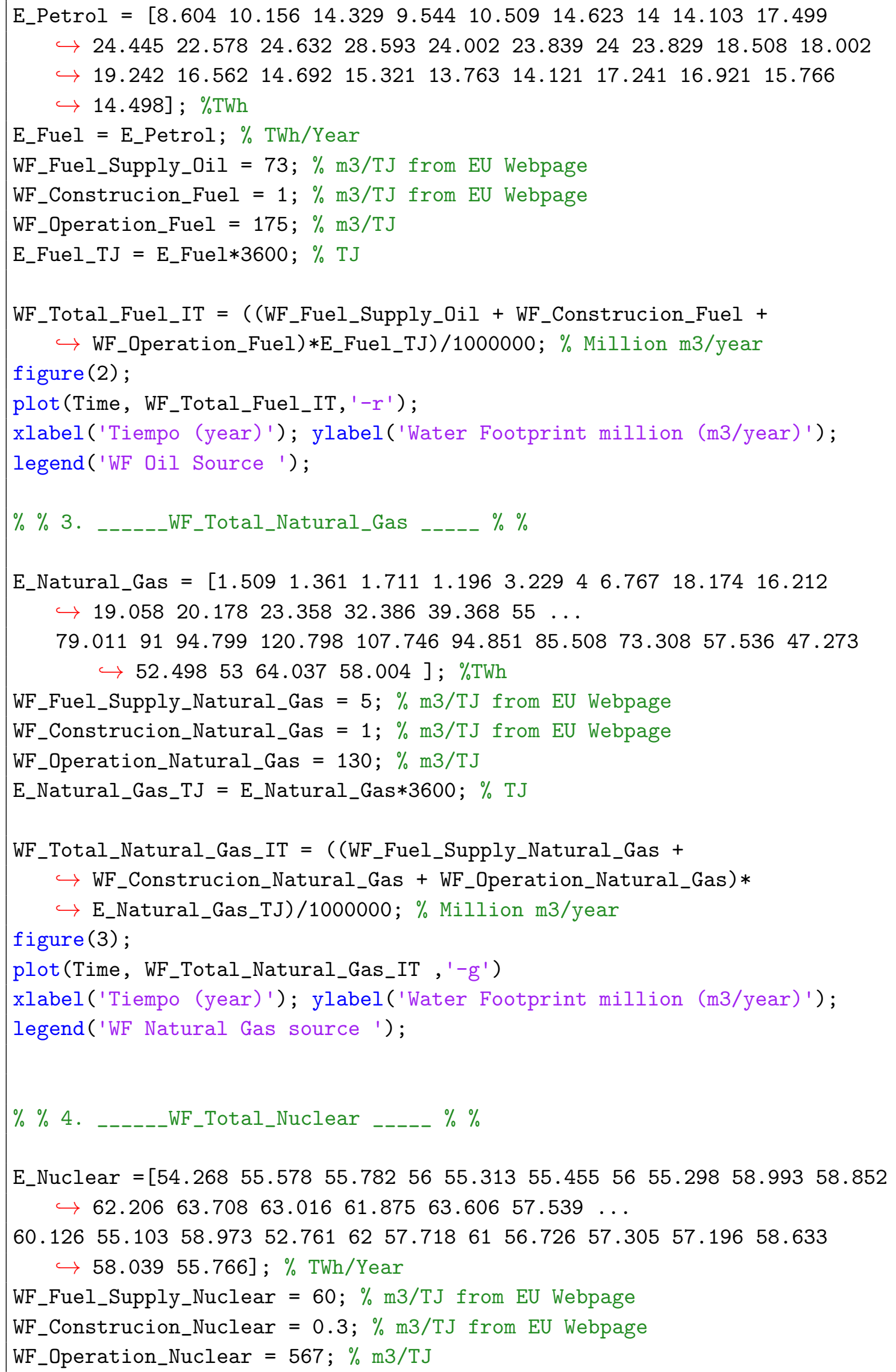




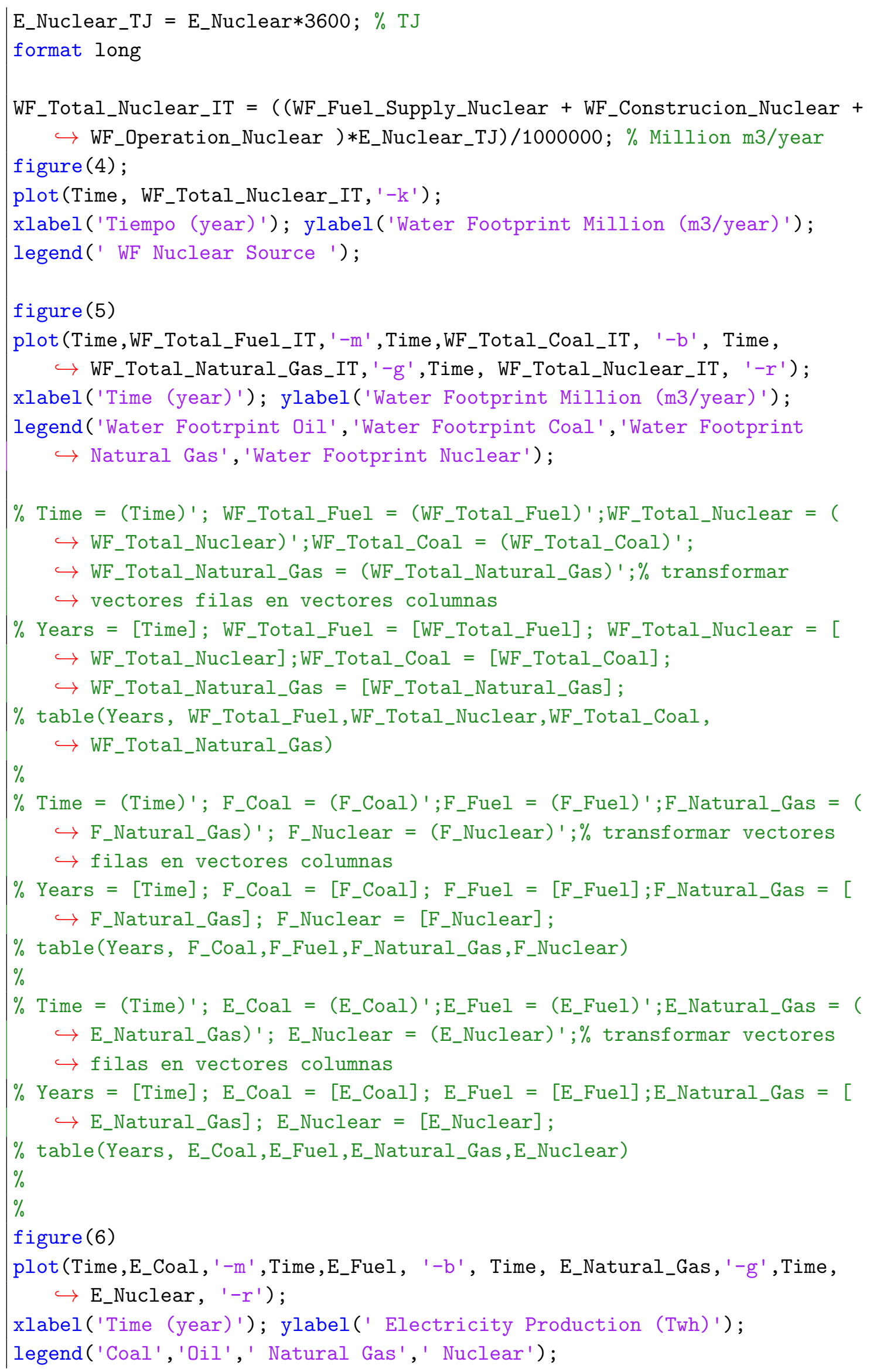




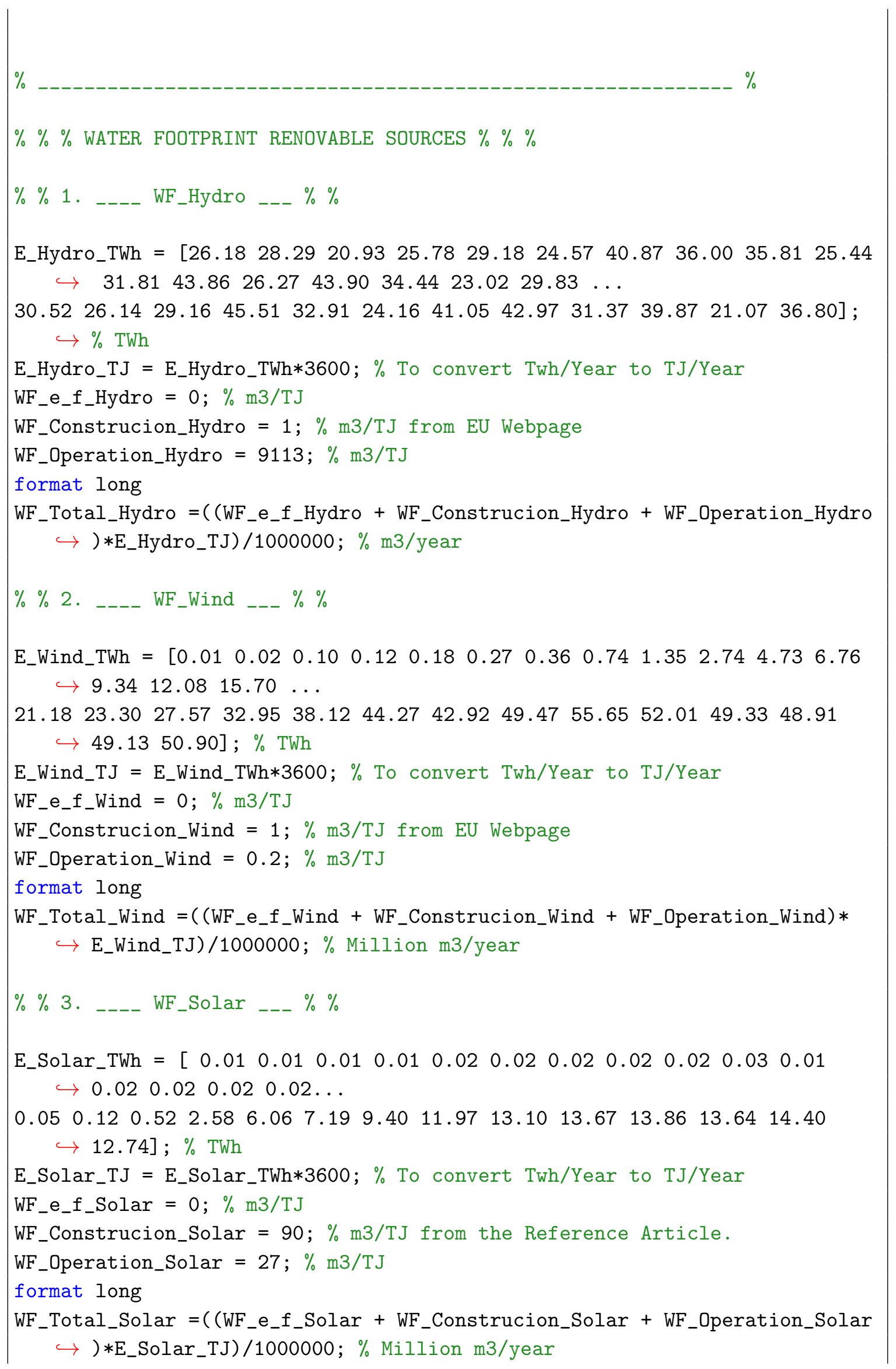


$\% 4$. WF_Biodiesel _-_ $\% \%$

E_Biodiesel_Solid $=\left[\begin{array}{llllllllll}0.54 & 0.54 & 0.56 & 0.57 & 0.61 & 0.86 & 0.94 & 1.31 & 1.37 & 1.43\end{array}\right.$

$\hookrightarrow 1.181 .30 \ldots$

$\begin{array}{llllllllllllll}2.11 & 2.43 & 2.50 & 2.03 & 2.17 & 2.29 & 2.67 & 2.96 & 3.17 & 3.81 & 4.11 & 4.83 & 4.51 & 4.78\end{array}$ $\hookrightarrow 4.785 .144 .98] ; \%$ Twh

E_Biogas $=\left[\begin{array}{llllllllllll}0.00 & 0.00 & 0.01 & 0.01 & 0.03 & 0.15 & 0.15 & 0.15 & 0.16 & 0.19 & 0.32 & 0.33\end{array}\right.$

$\hookrightarrow 0.47 \quad 0.76 \quad 0.82 \quad 0.62 \quad 0.60 \ldots$

$\begin{array}{llllllllllllllllll}0.61 & 0.58 & 0.53 & 0.85 & 0.80 & 0.87 & 0.97 & 0.91 & 0.98 & 0.91 & 0.94 & 0.92\end{array} ; \%$ Twh

E_Biodiesel = E_Biodiesel_Solid + E_Biogas; \% TWh $/$ Year

WF_e_f_Biodiesel_Blue $=3279 ; \% \mathrm{~m} 3 / \mathrm{TJ}$ from EU Webpage (Blue one. Take a

$\hookrightarrow$ look on the NOTE, abode of the table on EU Article.

WF_e_f_Biodiesel_Green $=134345 ; \% \mathrm{~m} 3 / \mathrm{TJ}$ from EU Webpage (Green one)

WF_Construcion_Biodiesel $=1 ; \% \mathrm{~m} 3 / \mathrm{TJ}$ from EU Webpage

WF_Operation_Biodiesel $=0 ; \% \mathrm{~m} 3 / \mathrm{TJ}$

E_Biodiesel_TJ $=$ E_Biodiesel $* 3600 ; \% \mathrm{TJ}$

WF_Total_Biodiesel_IT_Blue $=\left(\left(W F_{-} e_{-} f_{-} B i o d i e s e l_{-} B l u e+\right.\right.$

$\hookrightarrow$ WF_Construcion_Biodiesel + WF_Operation_Biodiesel) $* E_{\text {E_Biodiesel_TJ }}$

$\hookrightarrow / 1000000 ; \%$ Million m3/year

WF_Total_Biodiesel_IT_Green $=\left(\left(W F_{-} e_{-} f_{-}\right.\right.$Biodiesel_Green +

$\hookrightarrow$ WF_Construcion_Biodiesel + WF_Operation_Biodiesel) $*$ E_Biodiesel_TJ)

$\hookrightarrow / 1000000 ; \%$ Million m3/year

figure (7);

plot(Time, WF_Total_Biodiesel_IT_Blue, '-b', Time,

$\hookrightarrow$ WF_Total_Biodiesel_IT_Green , '-g')

legend('WF Biodiesel (Blue )', 'WF Biodiesel (Green)');

xlabel('Tiempo (year)'); ylabel('Water Footprint million (m3/year)');

WF_Total_Biodiesel $=$ WF_Total_Biodiesel_IT_Blue +

$\hookrightarrow$ WF_Total_Biodiesel_IT_Green; \% Million m3/year

E_Total_NoRenowable $=E_{-}$Coal $+E_{-}$Fuel $+E_{-}$Natural_Gas $+E_{-}$Nuclear $; \%+$

$\hookrightarrow$ E_Hydro_TWh + E_Wind_Twh + E_Solar_Twh + E_Biodiesel; \% Twh

E_Total_Renowable $=$ E_Hydro_TWh + E_Wind_TWh + E_Solar_TWh + E_Biodiesel;

$\hookrightarrow \% \mathrm{Twh}$

E_Total_ESP= E_Total_Renowable + E_Total_NoRenowable;

WF_Total_ESPANA $=$ WF_Total_Coal_IT + WF_Total_Fuel_IT +

$\hookrightarrow$ WF_Total_Natural_Gas_IT + WF_Total_Nuclear_IT ...

+ WF_Total_Hydro + WF_Total_Wind + WF_Total_Solar + WF_Total_Biodiesel;

figure(8); 


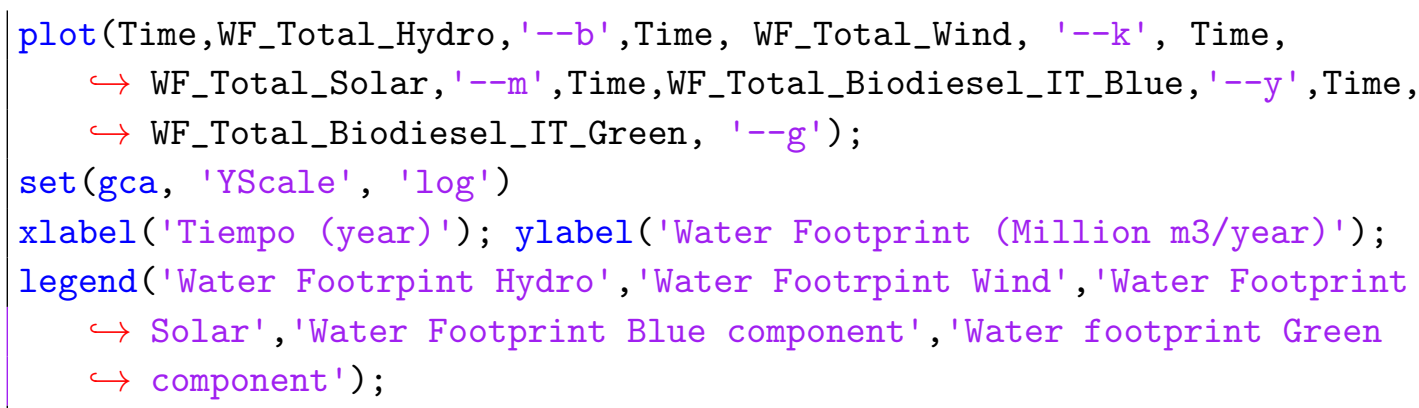




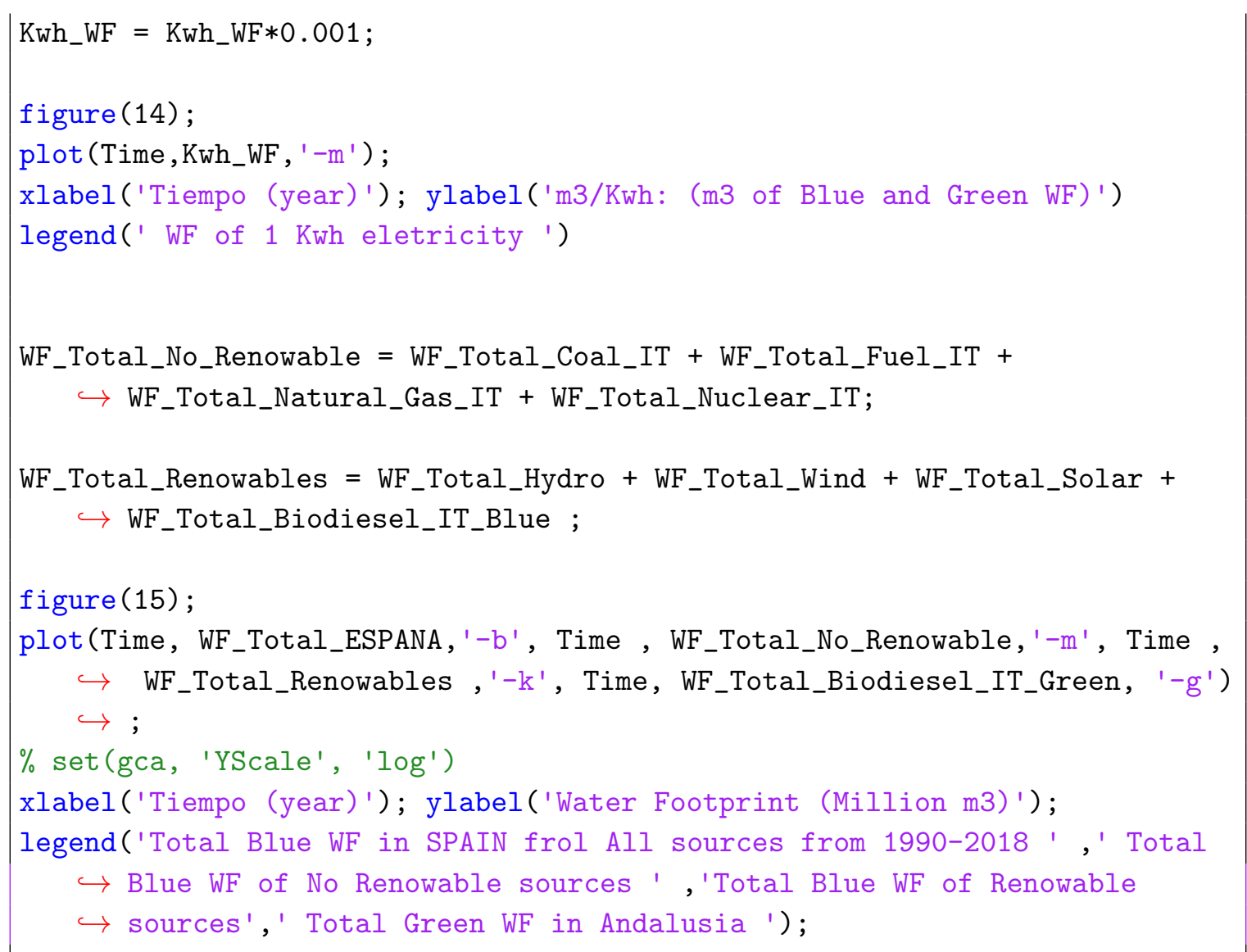

\section{B Appendix}

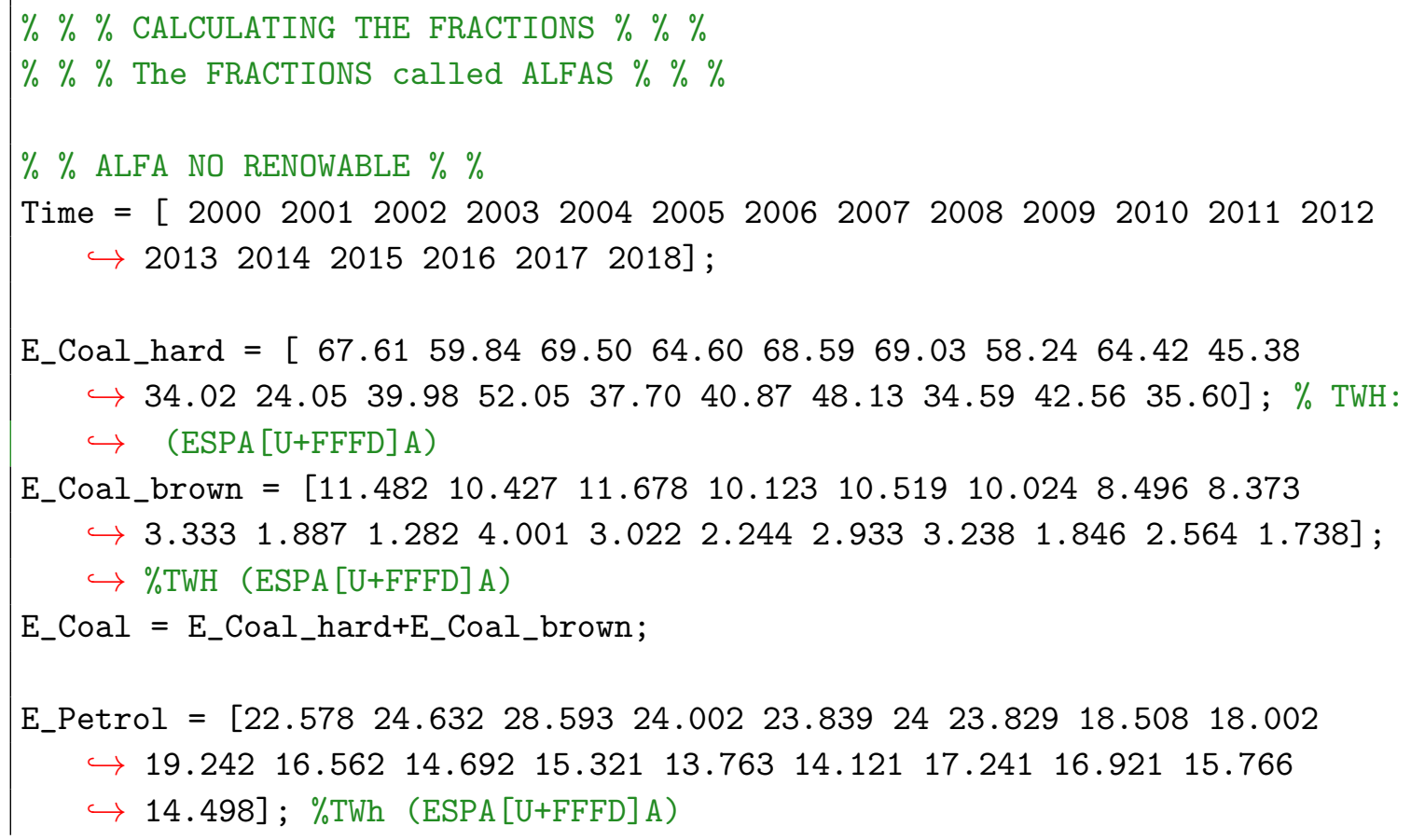




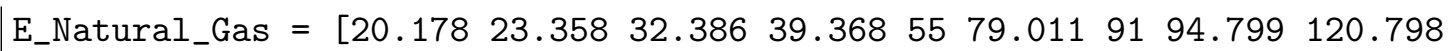

$\hookrightarrow 107.74694 .85185 .508 \quad 73.308 \quad 57.536 \quad 47.273 \quad 52.498 \quad 53 \quad 64.037 \quad 58.004$

$\hookrightarrow$ ]; \%TWh (ESPA [U+FFFD]A)

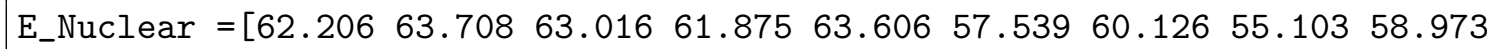

$\hookrightarrow \quad 52.76162 \quad 57.71861 \quad 56.726 \quad 57.305 \quad 57.196 \quad 58.633 \quad 58.03955 .766]$; \%

$\hookrightarrow$ TWh (ESPA [U+FFFD]A)

E_Total_No_Renowable $=$ E_Coal + E_Petrol + E_Natural_Gas + E_Nuclear;

$\%$ Alfa_Coal $=$ E_Coal/E_Total_No_Renowable;

$\%$ Alfa_Oil = E_Petrol/E_Total_No_Renowable;

$\%$ Alfa_Natural_Gas = E_Natural_Gas $/$ E_Total_No_Renowable;

$\%$ Alfa_Nuclear = E_Nuclear/E_Total_No_Renowable;

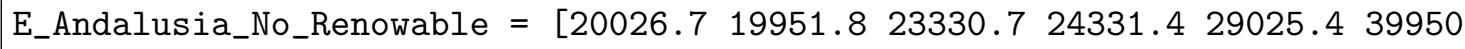

$\hookrightarrow 39060.2 \quad 40123.4 \quad 34329.8 \quad 32714.429330 .928922 .428074 .122240 .5$

$\hookrightarrow 20439.224887 .920995 .625281 .123784 .8] * 0.001$; \% is multiplicated

$\hookrightarrow$ to 0.001 to convert the Gwh to Twh

E_Andalusia_Renowable $=\left[\begin{array}{lllllll}1131.7 & 1792 & 1886 & 2334 & 2327.3 & 2517.3 & 2335.8\end{array}\right.$

$\hookrightarrow 2627.74386 .87615 .210170 .411250 .7 \quad \ldots$

$11664.214063 .512937 .1 \quad 12354.413230 .7 \quad 13467.5 \quad 12187.2] * 0.001$; \% is

$\hookrightarrow$ multiplicated to 0.001 to convert the Gwh to Twh

for $i=1$ : length (Time)

Alfa_Coal (i) = E_Coal (i)/E_Total_No_Renowable(i);

Alfa_Oil(i) = E_Petrol(i)/E_Total_No_Renowable(i);

Alfa_Natural_Gas(i) = E_Natural_Gas(i)/E_Total_No_Renowable(i);

Alfa_Nuclear(i) = E_Nuclear(i)/E_Total_No_Renowable (i);

E_Coal_ANDALUSIA $(i)=$ Alfa_Coal $(i) * E_{-}$Andalusia_No_Renowable $(i)$;

E_Fuel_ANDALUSIA (i) = E_Andalusia_No_Renowable(i)*Alfa_Oil(i);

E_Natural_Gas_ANDALUSIA (i) = E_Andalusia_No_Renowable(i) *

$\hookrightarrow$ Alfa_Natural_Gas (i);

E_Nuclear_ANDALUSIA $(i)=$ Alfa_Nuclear $(i) *$ E_Andalusia_No_Renowable $\hookrightarrow$ (i);

end

$\% \%$

Time $=(\text { Time })^{\prime} ;$ Alfa_Coal $=(\text { Alfa_Coal })^{\prime} ;$ Alfa_Oil $=($ Alfa_Oil)' ;

$\hookrightarrow$ Alfa_Natural_Gas = (Alfa_Natural_Gas)' $;$ Alfa_Nuclear $=($

$\hookrightarrow$ Alfa_Nuclear)';\% transformar vectores filas en vectores columnas

Years $=[$ Time $] ;$ Alfa_Coal = [Alfa_Coal $] ;$ Alfa_Oil = [Alfa_Oil $]$;

$\hookrightarrow$ Alfa_Natural_Gas $=[$ Alfa_Natural_Gas $] ;$ Alfa_Nuclear $=[$ Alfa_Nuclear

$\hookrightarrow$ ];

table(Years, Alfa_Coal,Alfa_Oil,Alfa_Natural_Gas,Alfa_Nuclear) 


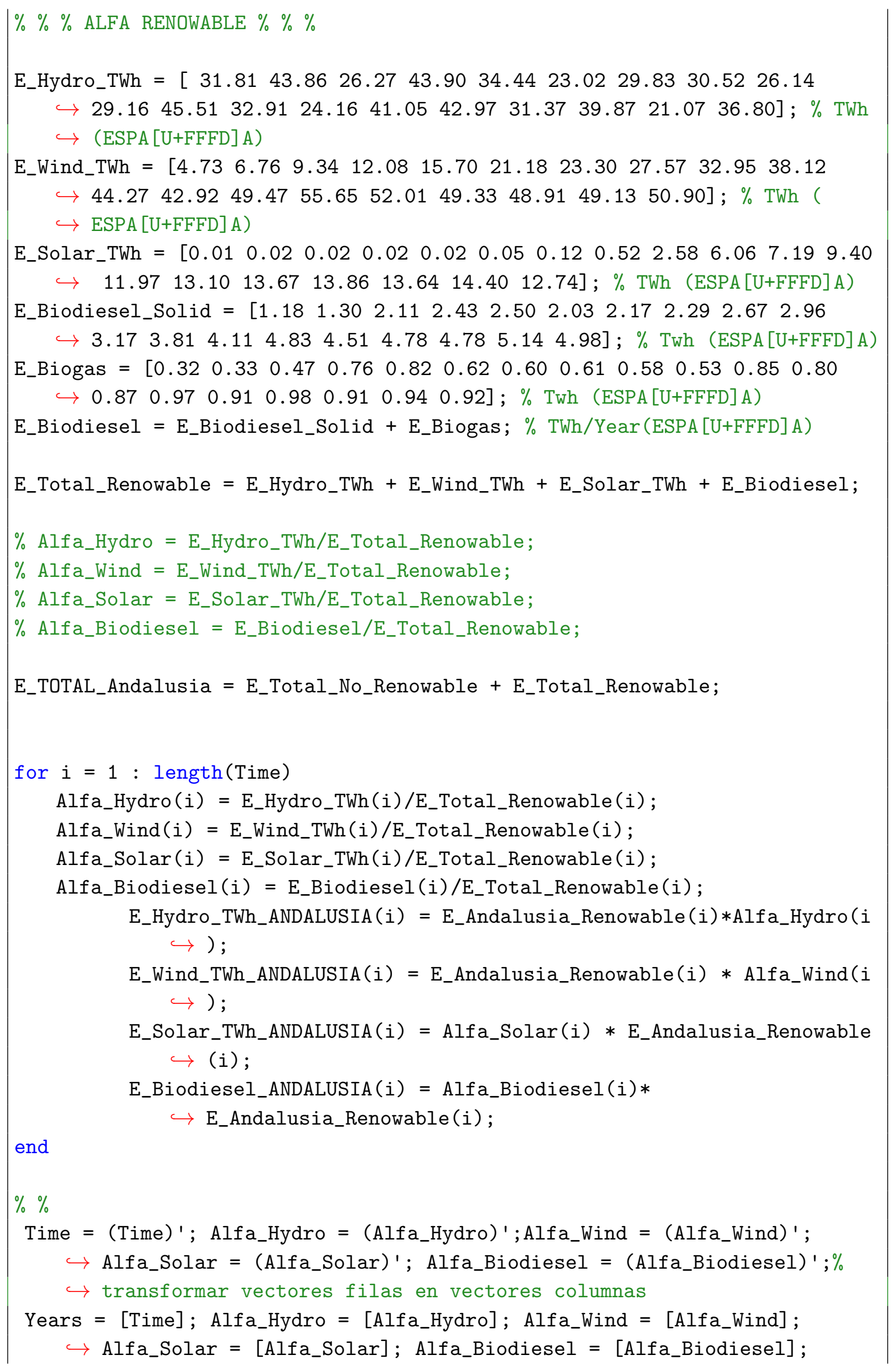


table(Years, Alfa_Hydro,Alfa_Wind,Alfa_Solar,Alfa_Biodiesel) 